University of Louisville

ThinkIR: The University of Louisville's Institutional Repository

Electronic Theses and Dissertations

1939

\title{
The origins of the Louisville and Nashville Railroad.
}

Lolla Wurtele 1913-2006

University of Louisville

Follow this and additional works at: https://ir.library.louisville.edu/etd

Part of the United States History Commons

\section{Recommended Citation}

Wurtele, Lolla 1913-2006, "The origins of the Louisville and Nashville Railroad." (1939). Electronic Theses and Dissertations. Paper 1857.

https://doi.org/10.18297/etd/1857

This Master's Thesis is brought to you for free and open access by ThinkIR: The University of Louisville's Institutional Repository. It has been accepted for inclusion in Electronic Theses and Dissertations by an authorized administrator of ThinkIR: The University of Louisville's Institutional Repository. This title appears here courtesy of the author, who has retained all other copyrights. For more information, please contact thinkir@louisville.edu. 


\title{
UNIVERSITY OF LOUISVILLE
}

THE ORIGINS OF THE LOUISVILLE AND

NASHVILLE RAILROAD

\author{
A Dissertation \\ Submitted to the Faoulty \\ Of the Graduate School of the University of Louisville \\ In Partial Fulfillment of the \\ Requirements for the Degree \\ Of Master of Arts
}

Department of History

By

LOLLA WURTELE 
Name of Student: LOLLA WURTELE

Title of Thesis: THE ORIGINS OF THE LOUISVILLE AND NASHVILLE RAILROAD

Name of Director:

Approved by a Reading Committee composed of the following members:

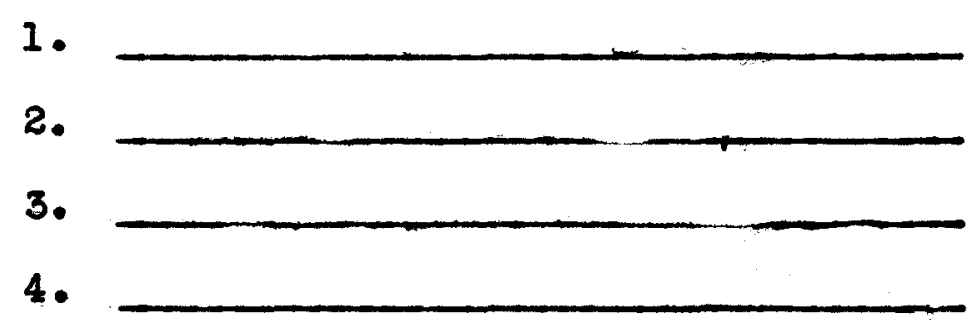

Representative of the Department of English:

Date: 1939 
THE ORIGINS OF THE LOUISVILLE AND NASHVILLE RAILROAD 
TABLE OF CONTENTS 


\section{TABLE OF CONTENTS}

CHAPTER

I

II

III

IV

V

THE FIRST STEPS TOFARD THE

BUILDING OF THE L AND N

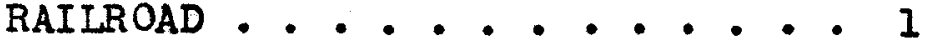

SURVEYS. • . • . . . . . . 27

LOCATION AND ESTIMATES . . . . 39

CONSTRUCTION . . . . . . 56

FINANCES . . . . . . . . . 71

BIBLIOGRAPHY . . . . . . 89 
THE FIRST STEPS TOWARD THE BUILDING OF THE I AND N RAILROAD 


\section{THE FIRST STEPS TOWARD THE BUILDING \\ OF THE L AND N RAILROAD}

The world to-day is passing through a second age of mechanization. "The invention of the steam engine and the development of the railroad throughout the years that have intervened between these two periods have shaped the lives of millions and influenced the social, politioal and economic forces whioh govern living conditions and national problems. The first machine age brought forth all of our present-day evils of the capitalistic system. Unemployment, migration from farm to city, unchecked production and other problems have been the bitter and constant complaint of the multitudes since the days of Thomas Carlyle."l

The first railroad traffic in both the south and the west came directly from agriculture. The cotton, tobacco, corn and other agricultural products of the South and the grain from the West found a market beyond the limits of their own territories. This was not an unusual situation but was 1. Kerr, John Leeds, The Story of a Southern Carrier, p.1 
merely a reflection of world-wide experience in the development of a nation. ${ }^{1}$ The rallroad thus made for greater national economic unity.

The railroads have developed America. It is true that there were millions of people in our country before a rallroad was even dreamed of, but it is also true that since the first rallroad started in 1830, the population has increased over nine-fold. The population of our country has increased from $12,000,000$ in 1830 to $105,000,000$ in 1920. There can be no doubt that the great natural resources of this country would have been developed to some extent without railroads, and millions of people would have sought a comfortable home in the new land of opportunity, but certainly the United States would not be the country it is to-day were it not for the railroads. The rallroads made new trading centers. The railroads ventured into sparsely settled lands, and within a few years thereafter cities grew up, wealth accumulated, and millions of acres of unworked lands were producing foodstuffs and other necessities for the nation. ${ }^{2}$

1. Kerr, ope cit., p. 3 .

2. A Book About the L and N, P. 6 . 
Although a number of short railroads had been constructed in the $1830^{\circ} \mathrm{s}$ (e.g. the Lexington and Louisville), the discovery of gold in California gave impetus to a vigorous movement of railway construction throughout the nation. The sudden addition of more than fifty million dollars in new wealth annually in circulation had a remarkably farorable effeot upon the industries and commerce of the country. 1

The first decade of American railway transportation (1830-1840) had several important charaoteristics. Physical difficulties were not the only or chief obstacles in the path of the early railway promoters in America. Until after the Civil War the steamboats and canals occupied the center of the transportation stage. Hater carriage had the advantage of easy demonstration, and the application of steam to river craft took precedence over land carriage until the smoothsurfaced track came to the aid of the primitive looomotive. Even then, the railroads were mostly used to connect waterways. Rates were generally

1. A Book About the I and N, p. 7 
based on the canal rates which had previously existed. I The equipment was of the most experimental sort. Experiments were made with the rails, ties, and foundations that were replaced with wooden sleepers, stone ballast, and T-rails that we have to-day. The mileage increase was also noteworthy. There were twenty-three miles in 1830 , but the mileage had expanded to 2,218 in 1840. The average cost during this decade was about $\$ 44,500$ per mile.2 Several American railroads readily adopted the English standard gauge, four feet, elght inches, but most of them used the gauge which seemed to meet their conditions best. Many of the Southern roads chose five feet as a standard gauge. Several of the later roads of this decade had iron rails; but the majority still used the wooden rail with a strip of iron attached. All

1. Thompson, Slason, Short History of American Railroads, pp. 47-48. The standard rate for moving freight on canals was $3 \not \subset$ per ton mile in 1832. This is high when compared to rallway rates of later days, but it was taken as the basis of limitation in some of the earlier rallway charters. The Pennsylrania Railroad, for example, was not to charge over $2 \not \subset$ per ton per mile for freight; $3 \not$ per mile on through

2. Ibid., pp. 73-74. 
roads were short, and such a thing as making connections with other roads was almost unheard of. 1

The difficulties of railroads in their first decade are very well summed up in the following statement:

Poverty and prejudioe presided at birth of rail-transportation in America, and panics rendered their early development fitful and precarious. Only the indomitable optimism of our race pushed the rails westward in advance of civilization. 2

The following ten years proved to be muoh more auspicious ones. On January 1, 1849, the first continuous line of railway from New York to Boston was formed with the opening of the New York and New Haven Railroad. The following spring, the Erie was completed to Lake Erie. The Michigan Central and Michigan Southern Railroads were completed, giving, with Lake Erie as an intermediate link, a connection between New York and Chicago in 1852.3

It was during these years, too, that America saw the awakening of the Ohio and Mississippi

1. Thompson, op. oit., p. 76

2. Ibid., $\mathrm{p} . \overline{81}$

3. Thompson, Slason, The Railway Library, 1910, p. 13. 
valleys to the importance of railway connections. In 1840 , Kentucky had only 28 miles of railroad; Tennessee, none; Indiana, none; Ohio, 30 miles; Illinois, none; Louisiana, 40 miles and Missouri, none. 2

In the South and Southwe st many small railroads were operating at this time. The panic of 1837 had ended most of the weaker companies and left only those short lines which were able to weather successfully the financial vicissitudes of the decades. One of our ablest miters of the history of the Mississippi Valley, R. S. Cotterill say 8:

The importance of the decade $1830-1840$ lies not so much in wat it did as in wat it intended to do. It outilned the rallway program for the next two decades and there was hardly a railroad bullt in the southwest before the Civil war that was not projected during this earlier period. 3

In the spring of 1845 a notable convention in the interest of railroads was held in Memphis,

1. Lexington and Frankfort Railroad running from Lexington to Frankfort to fouteril110-

2. Thompson, Short History, pp. T-5.

3. Cotterill, R. S., Mississippi Valley Historical Revien, vol. VIII, pp. 324-325. 
Tennessee. John C. Calhoun, Robert Y. Hayne, and James Gadsden, all famous rallroad exponents, were among those present. A general outburst of southern enthusiasm followed the adoption of the resolutions favoring the Pacific Rallroad. ${ }^{1}$

In 1845, also, the State of Tennessee chartered the Nashrille and Chattanooga which, when completed, would form in connection with the Charleston and Chattanooga Railroad, a through railway line from Nashville, Tennessee, on the Cumberland River, to Charleston, South Carolina, thus threatening Louisville's trade. The next plan was to connect Louisville on the Ohio with Charleston. Had this plan worked, it would have been highly remunerative from a traffic standpoint. At some later date a connecting line to Memphis could be attempted. 2

By 1850 the railway mileage of the country had more than trebled the figure at the end of the previous decade, and was distributed among twenty-five states while ten years before only nineteen states had any railway mileage at all. Of

1. Cotterill, op, cit, $\nabla 01$. III, pp. 432-434. 2. Kerr, ope ait., p. 11 . 
this sum, Kentucky had 78 miles; Louislana 80 miles; Alabama $75 \mathrm{miles}$; and Illinols $11 \mathrm{lmiles}$.? By the end of the next decade, (1860) the railroads of our growing country may be said to have passed successfully the experimental stage. By almost universal agreement the gauge had been fixed at 4 feet $8 \frac{1}{2}$ inches. By common consent the T-rail had practically supplanted all other forms of ralls. It was laid on wooden cross ties instead of longitudinal sleepers or stone blocks. The average weight of the rails was 56 to 60 pounds to the yard. The length of the rail had also increased from 18 to 30 feet. It was during this decade that the first steel rails were imported from England and placed in the line of the Pennsylrania Company. They cost $\$ 218$ per ton, which may be compared with the pre-war, (1914) price of $\$ 28$ per ton. But the invention in England of the Bessemer process, (1855) for manufacturing steel ingots that could be rolled into rails without hammering put an end to such a prohibitive price on steel rails. 2

1. Thompson, Short History of American Raliroads, p. 97. 2. Ibid., pp. 102-103. 
At this stage the American locomotive was a Gaudy affair oaparisoned, so to speak, with shining brass rods which it was the duty if not the pride of the crew to polish up so carefully that thousands of pounds of cotton waste and hundreds of "man-hours" were annually wasted in the useless process. One of the great economic reforms credited to Commodore Vanderbilt was the ordering that all these rods should be painted black, as they are to this day.l The first passenger cars resembled a stage coach having two decks, the women and children riding below and the men on top. By 1850, cars very similar to those we have today had come into use, a long body mounted on two four-wheeled bogies, first adopted in the United States to permit lengthy engines and cars to round the sharp curves with which our early Iines abounded. The side entrance which persists in England and Europe to-day had been abandoned for the end entrance and the center oorridor. 2 The one thing so important to present-day travellers

1. Thompson, Short History of American Railroads, p. 104. 2. Ibid., pp. 104-105. 
and not enjoyed by those of 1850 is the modern "sleeper." The trips in those days did not extend over a day and, if any one pelt the need of sleep he could ourl up on the length of a single seat. The roadbeds were light and the cars and engines were considerably lighter than our present day trains. The total tonnage transported in the country was about $5,000,000$ at a cost of four cents per ton per mile.l

What the railroad has done for the United States as a whole the Louisville and Nashrille Railroad has done for the south." 2 It was at a time when transportation needs were greatest between the Border States and the Lower South that the $L$ and $N$ was conceived. The men who projected the road were familiar with the economic situations of the two sections. These same projectors, it is safe to say, were among the most farsighted railway promoters of the day, because they looked on their interectional road as a means of preserving the Uni on and of tearing down economic sectionalism. ${ }^{3}$

1. Fiftieth Anniversary of James Geddes, 1901, p. 2 . 2. Clark, T. D., The Beginning of the L and N, p. 7 . 3. Ibid., p. 8 . 
It was in 1848 and 1849 that the idea of substituting railways for water transportation was seriously considered for the first time. The growth of population, commercial activity, and the increase in production and traffic demanded aditional transportation facilities. 1 The ohio River had always been the main artery of traffic to Louisville, but it was frozen during several months of the winter and of ten too low in summer. The city was at such times unable to ship its goods economically to merchants in Kentucky and Tennessee, or to obtain coal from the mines of Western Kentuoky. Residents of both Louisville and Cincinnati discussed the prospects of a railroad line which would extend south from the ohio River crossings to Memphis or some other point on the Mississippl where the river would be free of ice throughout the year. Leading oitizens in Tennessee were talking of railroads from Nashville to Chattanooga and to Western Kentucky. It looked as though Louisville would be threatened with commercial isolation and Nashville would

1. Johnson, J. S., Memorial History of Louisville, v.I, p. 320 . 
become the trade center of the South unless a rallroad were built southwestward from Loul sville.

The first to see the necessity of a link between Louisville and the South were the Louisville newspapers and through their influence smaller newspapers betweon Louigville and Nashville took up the agitation. The three most important papers in Loulsville, the Courier, the Journal, and the Democrat, from the very beginning fought vigorously for a railroad to run from Louisville to Nashville and they undoubtedly had a great deal of influence over their readers, for we find the City of Louigville voting between two and three millions of dollars in bonds for the Louisville and Nashville Railroad when it finally obtained its charter. ${ }^{2}$

It is well to bear in mind that when this project to build a railroad to Nashville was concelved, Louisville had a population of less than 45,000 people. It was a river town. Its business was concentrated along Main Street and

1. Kerr, ap. cit., pp. 6-7.

2. First Annual Report of the Louisville and Nashrilie Railroad Company, $1851, \mathrm{p} .6$. 
the volume of it was measured by the tonnage of the boats landing at the wharres between Second and Fifth Streets. Hence, at that day to build 185 miles of railroad was a huge undertaking. 1 The people, however, were extremely optimistic and falled to realize the tremendous difficulties that would have to be encountered before the completion of such an undertaking. On March 5, 1850, the Louisville and Nashville Railroad Company received its charter from the state of Kentucky and was given permission to organize. The state of Tennessee also conferred important and liberal powers upon the Company. 2 Great joy was manifested throughout the city and state and excitement ran high, but it was not until September 4, 1851, that books of subscription were opened and 1,058 shares of stock were sold. "The first payment on the stock subscription was $\$ 58.00$, of which $\$ 22.55$ was paid for advertising and the remaining $\$ 34.45$ was placed in the treasury." 3

1. First Annual Report of the Louisville and Neshrilie Railroad Company, 1851, p. 6.

2. Charter of the L and N, p. 1. Original in vault at $L$ and $N$ offices.

3. Story of the L and $N, p .10$. Published by the company. 
The original charter was made up of twenty-two sections. These seotions fall naturally into three distinct divisions. Sections I to $V$, inclusive, with sections $X I$ and XIII, provide for subscriptions to the authorized capital stock and incorporate the company. Some of the names listed as inoorporators were Colonel Thomas Anderson, James S. Speed, James Guthrie, Levin L. Shreve, and Villiam F. Bullock, all of the city of Louisville, Robert N. Miller, Joshua F. Speed and Edward D. Hobbs, of the county of Jefferson; J. S. Guthrio, John Cofer, John L. Helm, and George L. Miles, of the county of Hardin. These men were empowered to act as commissioners to receive subscriptions to the capital stock of the company in their respective counties. The total capital stock originally authorized was $\$ 3,000,000$ in shares of $\$ 100$ each. After due notice the capital stock could be increased to $\$ 4,000,000$ by the President and Directors. The Company was authorized to purchase, hold, sell, lease, and convey real 
estate not to exceed 10,000 acres. 1

Section III stated that if more than 30,000 shares shall be subsoribed to the capital stock of the company, the commissioners, or a majority of them, should reduce the subscriptions by striking of $f$ in succession from the largest number of shares subscribed by single individuals or corporations, until the subscriptions were reduced to thirty thousand shares, so as to equaIize the stockholders. 2

Section IV gives the plan of payment ${ }^{3}$ and gives the Board of Directors the authority to borrow an amount not to exceed $\$ 500,000$ if necessary.

Section $V$ made a ten year period the maximum time allowed for incorporation.4

Sections VI through $X$ and section XII dealt with the details of organization. When 2,000 shares of stock had been subscribed a twenty-day notice of

1. Charter of the L and N, Pp. 3-5.

2. Ibid., p. 3.

3. Section IV stated, "That at every subscription of stock the re shall be paid, at the time of subscribing, to the said commissioners, or their agents appointed to receive such subscriptions, either in money or a note negotiable and payable at some bank in the state, as said commissioners may elect, at sixty days' date or longer, at the option of the commissioners the sum of one dollar on every share subscribed, and the residue therof shall be paid in such installments and at such time as may be required by the Board of Directors."

4. Charter of the $L$ and $N, P .5$. 
a stockholders' meeting to elect directors should be given in one or more newspapers publi shed in Louisville, Bardstown, Glasgow, Elizabethtown, and Bowling Green. The seven directors, or a majority of them, were to elect a president, either from among the directors or from among other stockholders. Thereafter direotors were to be elected annually on the first Monday in June. The president and directors were given the right to call a meeting of the stockholders at any time during the interval between the annual meetings, provided they gave a thirty-day notice. This power was given also to stockholders holding as much as one-fourth of the stock. The president and directors, or a majority of them, were to appoint such officers, agents, or servants, as they deemed expedient for the business of the company, and to remove any of them at their pleasure. They were given the power to arrange the salaries of such employees and to erect warehouses, workshops, depots, and all other buildings necessary for the transaction of the company business. 1

1. Charter of the $L$ and $N, p p, 5-8$ 
The railroad mas to be constructed from Louisville, in the direction of Nashville, along a route, not exceeding 66 feet wide, selected and determined by the directors. They were to have as many tracks as might be found necessary and could cause contracts to be made with others for the making of the railroad or any part of $1 t$. They were also given the power to build bridges and construct tunnels, provided they did not obstruct the navigation on navigable streams. The tolls were not to exceed the following rates:
All goods, merchandise, or property $--3 \frac{1}{2} \not$ per mile for every hundred pound sarried over 20 miles and under 50 miles. For persons, and every species of live stock, and every other description of freight and property, --they could charge no greater rate than was authorizod to be charged on the Lexington and Frankf ort Railroad. 1

The legislature promised not to authorize any other railroad for the space of thirty years to be laid down on a parallel line within ten miles of the $L$ and $N$ road. 2

1. Charter of the $L$ and $N, p . I I$.

2. Ibid., p. 12. 
Section XX stated that if any person or persons willfully, by any means, whatever, injure, impair, or destroy any part of the $L$ and $N$ road or their buildings, or machinery, they would be forced to pay to the company a sum not exceeding $\$ 500$ and serve a term of not less than six months nor more than four years in the penitentiary. ${ }^{l}$ The road was authorized to commence and prosecute their business upon the terms agreed upon as soon as fire miles of their route had been completed. ${ }^{2}$ There have been in Kentucky 29 amendments to the original charter, mostly increasing the powers of the company and enlarging the scope of its operations. It has likewise inherited, through the acquisition of connecting lines, additional corporate rights in Kentucky, Tennessee, Alabama, Florida, Georgia, Louisiana, Ohio, and Missour1. 3 An amendment of March 20, 1851, authorized any three of the incorporators to open stock subsorlptions and provided for organization when the subscriptions reached $\$ 100,000$, instead of the

1. Charter of the L and N, p. 13

2. Ibid., pp. 14-16.

3. Story of the $L$ and $N, p, 14$ 
$\$ 200,000$ or 2,000 shares provided $f$ or in the original act. The second section of this amendment gave the company the right to construct its road from the oity of Loulsville to any point or place in the direction of Nashrille, and to connect the road with any railroad extending to Nashville if it so desired. It was also given the power to construct a branch of the road to the Mississippi River. This was meant to be a threat to Nashville in case the Legislature of Tennessee should be reluctant to grant a satisfactory charter. It would enable the $L$ and $N$ to connect with some Memphis road or even construct to Columbus, Kentucky, on the Mississippi. The right of way was extended to one hundred and fifty feet, and the amount of acreage to be legally acquired was to be exclusive of the right of way.l

The president and directors were to lay before the stockholders an annual report giving the cost of the road, as far as estimated, together with the amount of subscription obtained, the right of way obtained, and the expenses incurred.2

1. Charter of the L and N, p.15. 2. Ibid., p. 15 . 
Section VIII of the amendment provided that the company could pay as much as one-third of the contract price in the bonds of the company, having not less than ten years to run, and bearing not more than $6 \%$ per annum interest, paying half-yearly, and interest and prinoipal payable in some of the eastern cities, and to secure the same by deed of trust on the road. ${ }^{1}$ Another amendment, January 9, 1852, clarified the procedure in the case of county subsoriptions. The company was to make formal application to the county courts for subscriptions and the matter was to be put before the people of the counties for a vote within sixty days. If the rote proved to be in the affirmative, the counties were to be allowed to subseribe for as many shares as the voters wished and to pay for the stock with their county bonds, payable in not more than twenty years from the date of issue, and with an interest rate of $6 \%$. The county, on the other hand, was to levy a tax sufficient to pay the interest on the bonds and to designate three commissioners of

1. Charter of the L and N, p. 19. 
the sinking fund to handle the funds received. Dividends paid by the company on the stook omed by counties were to go into the sinking fund of the county and where the dividends were not sufficient to retire the bonds the counties were empowered to take measures to meet the obligation. 1

An Act passed on February 24, 1854, states that all lands within the counties were subject to a railroad tax, whether held or owned by people living in the county or persons outside. It provided also that in all elections of the $L$ and N Railroad Company, the General Council of Louisville could appoint some person, in the absence of the mayor, to cast the vote of the city. Also that the commissioners of the sinking fund of each county might appoint one of their number to case the county vote. 2

An amendment passed March 7, 1854, made it lawful for the $L$ and $N$ Railroad Company to increase its capital stock to any amount desired by the president and directors of the company. This

1. Charter of the L and N, P. 20

2. Ibid., p. 28 
was not, however, to exceed the entire cost of the road and its branches. It could redeem its bonds so long as they were redeemed at par or under. It was also authorized to issue bonds under a second mortgage of the road and branches to any amount deemed necessary provided that the full amount of the second mortgage bonds did not exceed one-third the cost of the road and its branches. It was given the power in this act to unite the road with any other road it might desire to unite with. It was made lawful, also, for the company to decimate its stock and to issue fractional certificates from one to nine-tenths of a share, provided, that all such shares isgued were aggregated into full shares within one year after the first dividend was deolared by the company. 1

In the next amendment, approved by the Legislature of Kentucky on January 17, 1856, was a section dealing with slave labor on the road, but not for traffic. When they were no longer needed they could be sold either in Tennessee 
or Kentucky. This proved very satisfactory to the road because of the high cost of labor in the north. 1 slave labor made it possible to build the road at a much lower price than northern rallroad companies were. paying. ${ }^{2}$

The Act also empowered the $L$ and $N$ to build a bridge across the Cumberland River and to purchase land $f$ or warehouses and depots in Tennessee. The Act required, however, that the $\mathrm{I}$ and $\mathrm{N}$ complete, equip, and operate not less than thirty miles of its road next to the city of Nashville, including the bridge across the Cumberland River, by 1858. The $L$ and $N$ along with the Edgefield and Kentucky Railroad was given $\$ 100,000$ by the State of Tennessee to build the Cumberland River bridge. The tro roads were consolidated for this purpose and given the sum of $\$ 200,000$ for which the governor issued bonds of the state at $6 \%$ at thirty years, to be issued as $\$ 20,000$ of the work was completed from

1. Charter of the $L$ and $N$, p. 34.

2. Cotterill, R. S., Missi ssippi Valley Historical Review, vols. III and VIII. 
time to time. I The two roads were authorized to unite in track construction across the Cumberland River.

At later dates the $\mathrm{L}$ and $\mathrm{N}$ was authorized to build and operate branoh roads, and to issue bonds $f$ or their construction and equipment. Other amendments relate to rates both on the main line and the branches of the road. When it became a settled fact that the road would be built from Louisville, the smaller towns along the way immediately began urging the company to run the line their way. A meeting was held in Russellville, on January 25, 1851, to decide the best course to take to secure a place on the new road. The local oitizens approved a petition to the state Legislature requesting that Logan County be permitted to raise $\$ 300,000$ by county tax subscription. Bowling Green, believing this idea of large subscriptions would turn the trick, held a similar meeting in March of that year and subscribed $\$ 1,000,000$ to the

1. Charter of the L and N, p. 36 . 
Bowling Green and Tennessee Rallroad. 1 Two possible routes were known at this time. One called the Glasgow route left Louisville and approached Nashville by way of Bardstown, New Haven, Glasgow, and Gallatin. This route was considered good because of the great interest manifested by the citizens of those towns, but the "Air-line" route, via Elizabethtown, Mundfordv1lle, Bowling Green, Franklin, and Gallatin was considered the best beoause it passed through the counties of Edmonson, Hart, and Warren, which of fered the distinct advantage of large coal beds and a proximity to the Memphis road. 2 It was considered advantageous to the company also, to have Bowling Green on the road, because of its size and apparent interest in the development of a railroad in Kentucky. ${ }^{3}$ The choosing of the route was to be left, however, to the Chief Engineer and the directors of the company. It is needless to add here just how much the

1. Clark, op. cite, pp. 26-29.

2. Soe map, p. 69 .

3. Clark, op. oit., p. 29. 
company was influenoed by the stand taken by the citizens of the various towns, through their local newspapers, and by the promises of large subscriptions. 
SURVEYS 
CHAPTER II

\section{SURVEYS}

Because of the great enthusiasm and interest shown by the people of Louisville and their bellef that the proposed railroad to Nashville would make Loulsville one of the most important cities in the United States, 1 the General Council of the city of Louisville passed a resolution in June, 1851, appointing a committee with the authority to engage an engineer to make a reconnaissance of the route from Louisville to Nashrille, and to place a party in the field for the purpose of making a preliminary survey. The committee chose a native of Louisville, Mr. L. L. Robinson, formerly of the Lexington and Ohio Railroad.2 To cover the expenses of the surveys, the Council made an appropriation of $\$ 4000.3$ Two parties were organized and equipped immediately. Mr. Robinson, in company with Colonel Wm. Riddle,

1. Loul sville Courier, July 11, 1851.

2. First Annual Report of the $L$ and $N$ Co., p. 3 .

3. Journal No. I Common Council City of Loui sville, 1851-52, $\mathrm{pp} .62-4$. 
Joshua F. Bullitt, and S. B. Thomas, left Louisville late in July, 1851. The other party was to commence work at the intersection of Seventh Street and Broadway, in Louisville, in september of the same year. 1

While the surveys were being made, steps toward organizing the railroad corporation were taken. On August 1, 1851, three of the commissioners named in the oharter, James Guthrie, Joshua Speed, and Robert N. Miller, caused notices to be published in the newspapers of Louisville that they would open books at the office of Guthrie and Tyler for subscriptions to the stock in the Louisville and Nashville Railroad Company on September 4, 1851.2 Success came almost immediately. The books were closed when the subscriptions had gone over $\$ 100,000$, and notice was given to the stockholders that a meeting would be held in the Mayor's office on September 20, to eleot the seven directors. 3 on September 27, the direotors were duly qualified,

1. First Annuel Report, p. 4 . Minute Book I Journal No. $\bar{I}, 1851-52$, pp. 64-65.

2. Minute Book I, 1851 City Counc1 I, Journal I, 1851-1852. Loulsville Courier, August 1-31, 1851.

3. James Guthrie, George S. Douglass, Wm. Riddle, John L. Helm, G. B. Adams, Eugene Underwood, Levin L. Shreve. 
and the $L$ and $N$ Railroad Company was fully launched on its corporate existence. ${ }^{1}$ The seven directors in turn elected the company's first president, Mr. Levin L. Shreve, and its first secretary, Mr. Wm. Riddle. 2

The newly elected executives found plenty of work awalting them, for Mr. Robinson had returned from his preliminary survey and was ready with his report. Two possible routes from Louisville to Nashrille had been found. One, called the "Air-line" route, went through Shepherdsville, Elizabethtown, Munf ordville, Bowling Green, Franklin, Gallatin and on into Nashville. The other, known as the "Glasgow" route, would take the road from Loui sville, via Bardstown, New Haven, Glasgow, Scottsville, and Gallatin, to Nashville.3 Mr. Robinson told the Board of Direotors that these preliminary explorations served to familiarize him with the principal or marked features of the country between Louisville and Nashville, and made him aware

\footnotetext{
1. Journal I, 1851-52. Louisville Courier, Sept. 28, 1851. Minute Book I, 1851 .

2. CIty Council, Journal I, 1851-52. Louisville Courier, September 29, 1851. First Annual Report, 1851.

3. Report of the Chief Engineer, 1854. p. 12 . see map on next page.
} 


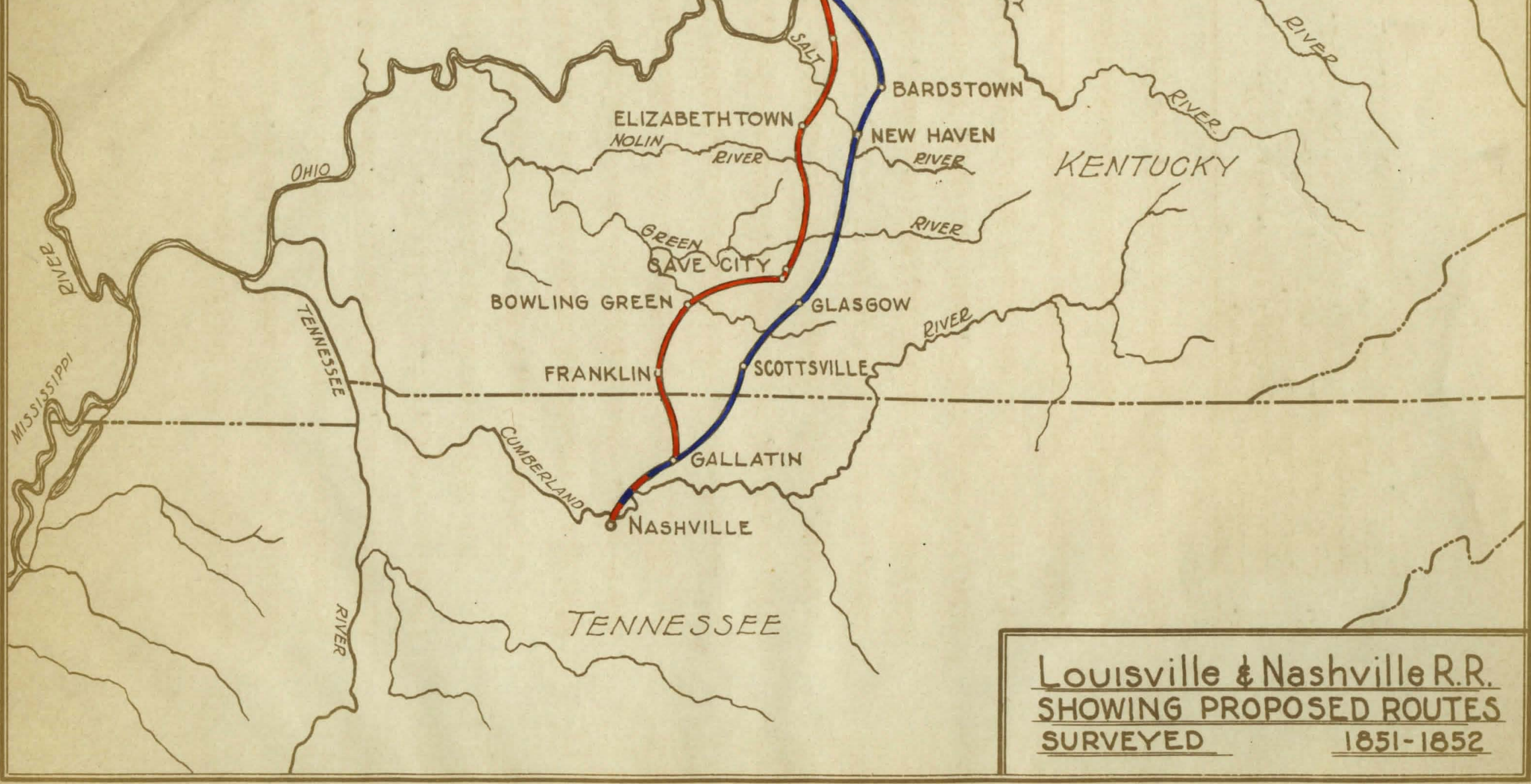


of the fact that the section of country to be traversed by the proposed road was most formidable. He stated, further, that it would require a vast amount of engineering examination to determine the best route. Mr. Robinson knew that it would take many months of hard work to decide upon the best possible route, so suggested to the directors that they use this time to arouse more local interest among the counties involved and thereby get more subscriptions for stock in the company. ${ }^{1}$ This suggestion, while probably not exactly an honest one, proved to be very successful.

The new president, with the ald of his directors, set to work immediately to discover the most direct and eligible route between the two terminif of the road. Upon the return of the expedition which had completed the preliminary reconnaissance, the engineers were organized for field service. They were divided into four groups, all under the supervision of James P. Robinson. The first group had as its task to find a

1. Surveys were made in all surrounding counties just to arouse hope in the citizens, for each county thought that the survey meant that the road would come that way.

2. Report of Chief Engineer, 1854, p. 18. Iinute Book I, $1851-52$ Gity Journals, $1852-53$ 
way to conquer Muldraugh's Hill and from there a route to Elizabethtown. Two routes were found. One would go via Mill Creek and would necessitate heavy construction work, many bridges, some very high above the beds of the rivers because of the frequent overflow of these streams, and at the base of Muldraugh's Hill it would be necessary to construct a tunnel 1,900 feet in length. The other route would follow Mill Creek a little farther and construct a tunnel 600 feet in length. Onoe the summit of Muldraugh's Hill was reached the rest would be ordinary construction work, provided the drainage was 1 ollowed down the hill to Green River. 1

The second group of engineers was organized under the leadership of John V. Gould. This group was to run a series of surveys from Louisville to Goddes Hollow, near Green River, by way of Sheperdsville and Bardstown. According to Gould's survey the route would follow the valley of Clear Creek to a point near the top of Muldraugh' Hill and then go through a tunnel 2,000 feet in length. At first

1. Report of Chief Engineer, 1854, p. 19 . 
Gould went into Bardstomn along Long Lick Creok, but when some of the more influential citizens of that town suggested another route the company ordered him to survey it also, because it helped a great deal in placing the subscriptions for stock in the company. 1

When both groups had reported their findings it was seen immediately that only two of them were practicable, the one first mentioned by the Mill Creek route, and the one surveyed along Clear Creek by Gould's party. These presented fewer obstacles and both fulfilled the requirements as to crade and curvature. 2

After a re-examination of the route by way of Clear Creek had proved it was shorter and cheaper of construction than the Mill Creek route, and also because of influential people along this route, the Board of Directors, in September, 1852, definitely decided upon the clear creek route. 3 On the other end of the line a third party

1. Report of Chiel Engineer, 1854, pp. 24-25.

2. The maximum grade on the route chosen was to be 70 leet to the mile, while the minimum radius of curvature mas to be 955 feet.

Report of Chief Engineer, 1854, p. 23.

3. Ibid., p. 37 . 
of engineers had been organized by M. B. Hewson and had begun its survey on the north bank of the Cumberland River opposite Nashville. It was the particular duty of the engineers to examine all routes between Nashville and Bowling Green, Nashrille and Gallatin, and Gallatin and Bowling Green. 1

A fourth party was busy surveying the route to Nashville by Glasgow and Scottsville. Its report shows that the Bowling Green route was superior in grades and curvature and therefore, would be less costly. 2

A great deal of time and money had already been spent in preliminary surveys. Before 1852 no less than six engineer corps had been put in the field, exploring as many different routes between Louisville and Nashville. Up until the latter part of 1852, these parties had surveyed over 2,000 miles of territory, and reported a total expenditure of $\$ 24,598.52$, or an average of about $\$ 12.50$ per

1. Report of Chief Engineer, 1854, p. 27.

2. Ibid., p. 33 . 
$\operatorname{mile} .^{1}$

Of all the routes explored the Company finally decided upon the Bowling Green route. This decision was caused by sereral important factors. From the engineers' viewpoint it was desirable because it showed less rise and $f$ all, less curvature, less construction cost, could be built more quickly, and when finished, trains could run over it in a shorter time and more economically. 2 From a financial standpoint it was easy to see the possible advantages of having so prosperous and thriving a town as Bowling Green on the road, both because of the many shares of stock sold to Bowling Green citizens and because of its proximity to the rich coal fields of that section of the state. 3 Moreover, the people of Bowling Green had become impatient to be declared a point on the road, and not being able to hasten the company prematurely in such a decision, had in the summer of 1852, organized a company under a charter granted by the States of Kentucky and Tennessee, March 5, 1850, and February

1. Annual Report of $L$ and $N$ Co., 1852 .

2. Report of Chief Englneer, 1854, p. 38 .

3. Ibld., p. 40 . 
13, 1852, under the title of the Bowling Green Railroad Company. It was the purpose of this company to complete a road to Nashville, Tennessee.' The Louisville and Nashville Railroad felt that this was the most serious obstacle that had presented itself, and so lost no time in passing a resolution authorizing President Shreve to negotiate with the Bowling Green Railroad Company for an amalgamation of the two companies. 2 The negotiations were made and the Bowling Green road with all its rights, privileges, and restrictions was assigned to the $L$ and $N$ Railroad Company.

The decision to make Bowling Green a point on the road affected all subsequent points and alignments. Elizabethtown, the county seat of Hardin County, Kentucky, was considered as an intermediate point between Loulsville and Bowling Green. A petition to the County Court of Hardin was filed on May 29, 1852, for a subscription of

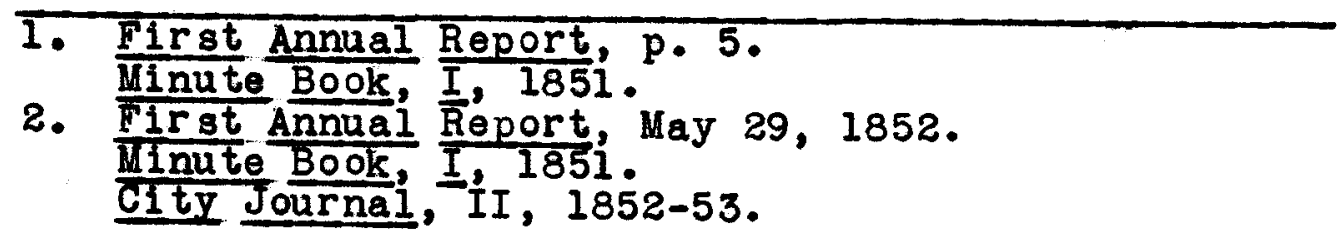


$\$ 300,000$, or 3,000 shares of stock in the Company, payable in the bonds of the county, bearing $6 \%$ interest, and having twenty years to run. The vote was taken on July 10, 1852, and resulted in favor of subscription, on the condition that Elizabethtown be made a point on the road. The company accepted the 3000 shares of stock and declared Elizabethtown to be a fixed point on the main stem to Nashville. 1

The Tennessee Ridge, bordering on the Cumberland Valley, could only be passed successfully by running the line through Gallatin, Tennessee, the county seat of Sumner County. To go through Gallatin would increase the route a little over five miles. Consequently it became necessary to secure the aid of Sumner County to ensure the success of this enterprise. The Company made the same petition to Sumner County that it had made to Hardin County. The rote was taken on July 24, 1852, and having been found favorable the subscription was accepted on the 20th of August, 1852, and

1. Annual Report of $L$ and N, p. 5 . Iinute Book I, I852. 
Gallatin was made a fixed point on the main line.1

Total subscriptions to the capital stock of

the company at this time were as follows: ${ }^{2}$

City of Louisville

City of Louisville (conditional)

Hardin County

Warren County

$\$ 100,000$

900,000

300,000

300,000

$\$ 1,600,000$

To which may be added contingently

Hart County

Simpson County

$\$ 100,000$

100,000

Individual subscriptions in

Bullitt

Farren

40,000

Simpson

50,000

50,000

Sumner County, Tennessee

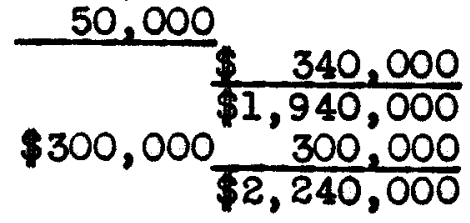

This amount would complete the road from Louisville to Gallatin. The remaining money to cover the last twenty-six miles to Nashville would have to come from Tennessee.

1. Annual Report of $L$ and $N, p .5$ Minute Book I, 1852

2. Ibid.1 1852 Annual Report of $L$ and $N, p .6$

3. Annual Report of L and N, 1852, p. 7 
LOCATION AND ESTIMATES 


\section{CHAPTER III}

\section{LOCATION AND ESTIMATES}

The Board of Directors, having made Bowling Green a point on the line, May 29, 1852, Elizabethtown, July 10, 1852, and Gallatin, August 20, 1852, and feeling sure that the finances of the company were in good shape, ordered the location of the road. A group of engineers under the leadership of James P. Robinson was put into the field to locate the right of way from Louisville to Elizabethtown. This was to be known afterwards as the First Division of the road. ${ }^{1}$

The exact location of the roadbed, as it had been agreed upon by the Engineers at the completion of the work of the several surveying parties, with the exception of a very few changes, was the same as to-day. It began at Broadray, between Ninth and Tenth Streets, and continued southward in a practically straight line for about nine miles

1. Report of Chief Engineer, 1854, p. 41 
beyond the city limits. From this point the construction work was light until the road reached Lebanon Junction. Of the 31.10 miles, there were 27.19 miles of straight line and 3.91 of curvature. The estimate of the cost of preparing the roadbed for the ir on was not particularly excessive, totaling $\$ 318,280$, or about $\$ 10,300$ per mile. Adding $\$ 388,500$ for ballast, rails, and side tracks, the sum of $\$ 706,780$ was obtained as the total estimated cost of the road from Louisville to Rolling Fork ${ }^{l}$ on Salt River. ${ }^{2}$

It was further estimated that the crossing of the Rolling Fork would cost nearly $\$ 55,000$ in addition to a great amount of earth fills. Then the road was located in 1853 by Mr. Robinson, it left the Rolling Fork and proceded southward by light grades and long curves, inter secting the foot of Muldraugh's Hill thirty-four miles out of the city of Louigville. In 1855, however, Mr. Macleod relocated this portion of the road and

1. Now known as Lebanon Junction.

2. Report of Chief Engineer, 1854, p. 51 . 
made several additional changes.

The heaviest work of the total distance from Louistille to Nashrille came between the base and the summit of Muldraugh's Hill. The distance was 4.87 miles, and it was surmounted with a maximum grade of 70 feet to the mile, and a minimum radius of curvature of 955 feet, making necessary many curves and heavy gradation. ${ }^{1}$ It was necessary to construct a tunnel through the crest of the H11l. This tunnel was 1,986 feet long and passed through 135 feet below the summit. The cost of grading alone on this section was said to be $\$ 520,000$, or about $\$ 104,000$ per mile. 2

From the top of the Hill on into Elizabethtown, the work was very light. From here to the point on Nolin River, 51.82 miles from Louisville, which was the end of the first division, the alignment was direct, the lowest curvature being on a radius of 5,730 feet. ${ }^{3}$

1. Report of Chief Engineer, 1854, p. 52 .

2. Ibid.. p. 55 .

3. Ibid., pp. 56-57. 
The Chief Engineer in 1854 gave the following summary of the first division of the road: ${ }^{1}$

Cost of gradation: $\$ 1,067,420$, or $\$ 20,500$ per mile. Mileage: straight, 36.64 ; curvature, 12.17; total, 48.81 .

Grades: up to thirty feet per mile--36.08 mlles

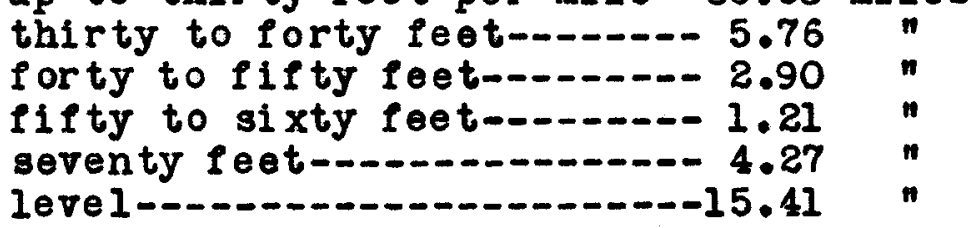

Total rise and fall, 1097 feet.

The Second Division was to extend from Nolin River to Bell's Tavern, about five miles north of Bowling Green. Very heavy construction was necessary from Nolin River to Green River. The greatest obstacle to present itself on this division was the crossing of Green River. 2 The necessary work here was estimated to cost $\$ 140,000 .^{3}$

1. Report of Chief Engineer, 1854, p. 57 .

2. The bridge finaliy construoted at this point was designed by Albert Fink in 1860. It was about 1000 feet in length, and 138 feet above the water. It was believed to be the largest iron bridge in America.

3. Report of Chief Engineer, 1856, p. 16. 
From this point on to the end of the Second Division the grades were light. The location was not changed a great deal by later surveys, the only important change being that the road was made to run in front of the stagecoach house at Bell's Tavern instead of behind that famous place. 1

The statistical summary for the Second Division was given as follows: ${ }^{2}$
Distance: total, 43.60 miles
Nolin River to Green River, 22.49 miles Green River to Bell's Tavern, 21.11 "
Gradients: level, 6124 miles grades (most of them light), 37.34 miles
Alignment: tangents, 32.87 miles: curvature, 19.73 miles. degree of curvature, 693.85 .
By combining the figures of the First Division with those of the second we see that the oost of gradation and fancing was about $\$ 1,868,882$, or nearly $\$ 19,672$ per mile. The cost of track and ballast was expected to add another $\$ 1,187,500$, making a total of $\$ 3,056,382$, or $\$ 33,000$ per mile. 3

1. Report of Chief Engineer, 1856, p. 15.

2. IbId., $1854, \mathrm{p} \cdot 70$.

3. Ibid., 1854, p. 70 . 
Going southward to Bowling Green, which was 113.22 miles from Louisville the road was continued by easy curves, light grades, and tangents from the end of the Second Division. With a very few exceptions the grades were 1ight. A bridge across the Barren River at Bowling Green was estimated at $\$ 50,000 .^{1}$ The summary of the estimated cost of the road to Bowling Green, including motive power, rolling stock and complete equipment was given as follors: ${ }^{2}$

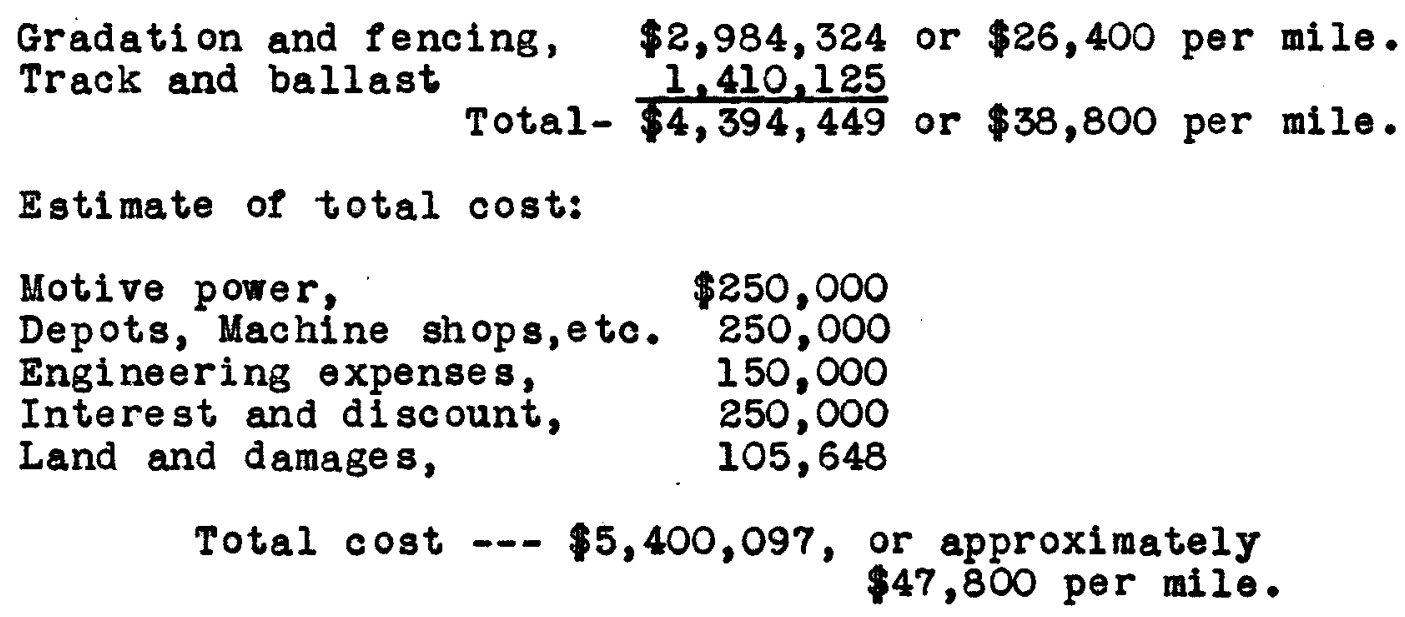

To the south of Bowling Green the extremely rolling nature of the country necessitated alternate

1. Report of Chief Engineer, 1854, p. 76 .

2. Ibid., p. 77 . 
ascending and descending grades. The road passed through Franklin, which is 21.29 miles bel ow Bowling Green. The alignment, however, was - direct, being nearly equivalent to a straight line, but the limestone formations, as well as the undulating character of the land, made it a region in which construction was expensive. 1

Very heavy work was found necessary to construct the Third Division of the road. This part extended from Franklin to the Tennessee State Line and was a distance of 5.76 miles. The alignment was direct and the few curres used were of large radius. The only engineering difficulties confronted were the crossings over Dry Branch and Sharp's Creek, both tributaries of Drake's Creek. The statistical summary of the Third Division was as follows: ${ }^{2}$

The total distances:

Section 96 to Barren River--17.81 miles

Barren River to Franklin----21.29 "

Franklin to State Line-...- 5.76 n

$$
\text { Total---- } 44.86 \text { miles }
$$

Alignment table:

Tangents, 38.71 miles; curvature, 6.15 miles. Degrees of curvature, 299.5

1. Report of Chief Engineer, 1854, pp. 78-79.

2. Ibid.. $\mathrm{pp} \cdot 83-84$. 
The estimated cost of gradation for the Third Division was $\$ 497,106$ or an average cost of $\$ 11,947$ per mile. This was so much lower than the cost of the First and Second Division that it was sufficient to lower the average cost of gradation from Louisville to the State Line to $\$ 16,900$ per mile. 1

From this point on into Nashville the going was not so good. The route was direct as to alignment and curves, while somewhat numerous, were to be of large radius; but the grades were among the heaviest in the entire road, since this portion of the road included the crossing of the Tennessee Ridge. To cross this Ridge, two tunnels were found necessary. The first was to be 730 feet 1 ong and 85 feet below the surface, the second was to be 600 feet long and 165 feet below the summit. Both were located on curves. The rock cutting alone involved an estimated expenditure of $\$ 225,000 .^{2}$ Gallatin was 18.68 miles south of the State Line. This

1. Report of Chief Engineer, 1854, p. 85 . 2. $\frac{\text { Ibid., }}{\mathrm{I} \cdot} \frac{\mathrm{Ch}}{88}$. 
section required heavy construction work and several bridges. Between Dry Creek and Edgefield Junction the route encountered twenty tributaries of the Cumberland River. The curvature between Edgefield Junction and Nashville was not excessive al though the number of degrees was large. Because of the facts mentioned above, the work was slow and difficult and the expense of building this section was high.l

The statistical summary was given as follows: 2

Total mileage, -........ 45.18 miles Level, 9.63 miles; ascending and descending, 35.55 miles.

Total rise and fall in feet, --1,667. Alignment: tangent, 29.2 miles; curvature, 18.98 miles.

The estimated cost from the State Line to Gallatin was $\$ 420,524$, and from Gallatin to Edgield, $\$ 560,112$. The average cost of gradation of this division was $\$ 21,791$ per mile, thus raising the total estimated cost per mile from Louisville to Nashville, a distance of 185 miles to $\$ 18,526.3$

1. Report of Chief Engineer, 1854, pp. 89-92. 2. Ibid., pp. 95-97.

3. Ibid., p. 105. 
The summary of the gradients, alignments, and estimated costs, for the entire road was as follows: ${ }^{1}$

Gradients: total distance, 185.45 miles. Level, 43.79 miles; ascending and descending grades, 141.64 miles.

Rise, 2,514 feet; fall, 2554 feet; total, 5,068 feet.

Alignment: Tangent, 140.42 miles; curvature, 45.03 miles.

Total degrees of curvature, $4,127.52$

Cost (gradation and fencing):

Kentucky, $\$ 2,365,988$; Tennessee, $\$ 1,979,636$.

Total, $\$ 4,345,624.00$

Added to this was the following table showing estimates per mile for the cost of equipping the road:

Track and ballast, - - - - $\$ 12,500$

Rolling stock and power- - - 3,500

Depots, turntables, etc. - - 2,000

Right of way, etc. - - - - - 750

Engineering expenses, - - - - 1,250

Interest and discount, - - - - $\frac{2,000}{52,000}$

Total - $\$ 22,000$

This would involve a cost of nearly $\$ 4,070,000$ for the entire system, which, added to the cost of gradation, would make the total cost of the road

1. Report of Chief Engineer, 1854, pp. 104-106. 
about $\$ 8,415,624$, or about $\$ 45,500$ per mile. ${ }^{1}$

Mr. L. L. Robinson included, in his report of 1854, careful directions for earth excavations. all materials taken from excavations were to be used in embankments, and the rock was to be placed on the road according to instructions. The roadbed was to be formed to a depth of one foot with clean gravel and sand. 2

Very definite instructions were given as to rock excavations, tunnels, embankment, ballasting and so forth. Stable foundations, concrete or rock, were to be used for all stone or permanent structures. If it became necessary to use wood it was to be oak in Kentucky, and either oak or cedar in Tennessee. Specification for cross ties, ballasting, iron and track was given in great detail. Every bit of material was to be of the best quality possible to obtain. 3 Along with this report Mr. Robinson added a detailed summary of the resources of the region which the $L$ and $N$ was to pass through, estimated

1. Report of Chief Engineer, 1854, pp. 110-115.

2. Ibid., $\mathrm{pp} \cdot \frac{\mathrm{ap}}{139-140 .}$

3. Ibid., pp. 144-146. 
the cost of operation, and then gave his ideas as to the ability of the road to pay back the stockholders for their investment. The land in the counties which this new road served was considered to be worth $\$ 192,834,000$ and had a total acreage of $10,046,017$. The population of this region was 488,956 and was largely rural with the exception of Loulgville and Nashville.1

Mr. Robinson listed the following estimates of traffic from Louisville to Nashville: ${ }^{2}$

Horse 3

Mules

Cattle

Sheep

Swine

Live stock of all kinds

Total pounds of Tobacco

Wool

Hemp

Flax

Cotton

Hay
174,369

42,999

390,996

590,680

$1,839,831$

$3,039,675$
$37,824,820$

985,472

$6,847,680$

$1,196,735$

$9,764,100$

$113,021,440$

1. Chief Engineer's Report, 1854, pp. 110-112 (quoting from Uni ted States Census of 1850) 2. Ibid., p. 112 . 
Total bushels

$\begin{array}{lr}\text { Wheat } & 1,143,201 \\ \text { Rye } & 156,405 \\ \text { Corn } & 32,368,052 \\ \text { Oats } & 1,872,018 \\ \text { Peas and Beans } & 109,871 \\ \text { Flaxseed } & 43,009 \\ \text { Other Seed } & 7,756 \\ \text { Other Grains } & 12,925\end{array}$

Total pounds of Butter $5,232,004$ Cheese Honey Beeswax 93,248 453,407 Honey sugar 292,503

Value of Home Manufactures 1,628,159

The Engineer's estimate of passenger travel in 1850 was given in great detail. The travelers from Louisville to Nashville in 1850 by stage coach were about 15,000 annually, at an average cost of twelve to eighteen dollars. About 5,000 persons travelled up or down the Ohio River each year, and private conveyances would account 1 or 5,000 more. The railroad was expected to quadruple this traffic, thus yielding nearly 100,000 through passengers annually. It was estimated that at least one-half of the river traffic would pass over to the $L$ and $N$ since the cost by railway would be less and 
the distance covered on an average in one-half the time. The railroads meeting in Nashville were expected to add another 15,000 through passengers per year. The above mentioned sources would yield approximately 115,000 through passengers each year. 1

A condensation of the traffic estimates for both passengers and freight, as given by the Chief Engineer, follows: 2

54,000 tons of through freight at $\$ 5.0925$ per ton, Mails and expresses,

115,000 through passengers at $\$ 5$ average,

171,500 tons of way and $100 a 1$ Preights, $\quad 376,850$ $\$ 275,000.00$ $40,000.00$ $\stackrel{575,000.00}{\$ 890,000}$ 125,000 way and local passengers, 187,500

If this had worked out as planned, it would have meant an average gross revenue of $\$ 8,000$ per mile, not including the branches.

In concluding his report, Mr. Robinson felt it wise to list the connections of the road as 1. Report of Chief Engineer, 1854, pp. 131-132. 2. Ibid., p. I31. 
10110\% s: ${ }^{1}$

At the nor thern terminus:
(1) the Ohio River - most important tributary to the road
(2) Louisville and Frankf ort Railroad
(3) Louisville and Covington Railroad (under construction)
(4) Loul sville and Cleveland Straight Line Railroad (under construction)
(5) Jefferson Columbus Rail road
(6) Fort Wayme and Southern Railroad (under construction)
(7) New Albany and Salem Railroad
At the southern terminus:
(1) Cumberland River, navigable both ways
(2) Nashville and Chattanooga Railroad
In addi tion:
(1) Lebanon Branch which diverged 30 miles from Louisville
(2) Southwestern Branch which diverged 113 miles from Louisville
(3) Barren River at Bowling Green

When the $L$ and $N$ Road was completed it would have the promise of twenty-four river and railroad connections. 2

Mr. Robinson olosed his report with the following words:

Permit me to state that early in the history of the enterprise I was impressed with its importance, --the

1. Report of Chief Engineer, 1854, p. 125. 2. Ibid. p. 125 . 
more I have examined the merits of the enterprise, the more have I become convinced that it is a legitimate undertaking, and one that will richly repay its projectors; the country requires its construction and the Road should be built as speedily as possible.1

When Mr. Robinson had completed his report and all of the estimates had been studied carefully, it was decided to complete the First Division as soon as possible and to put it into immediate service. In order to do this it was deemed advisable first to locate the depot in Louisville, and if practicable, to engage with competent parties for the building of work-shops on the depot grounds, and to contract for all their power, rolling stock, and other machinery, to be built in the shops. 2 On October 23, 1852, the Board ordered the location and purohase of the depot ground on Broadway, between Ninth and Tenth cross streets, extending to Kentucky street. The plot contained about twenty-three acres and was purchased for $\$ 35,500.3$

1. Report of Chief Engineer, 1854, pp. 125-126.

2. Second Annual Report, p. 9 .

3. Ibid., p. 9, also; City Journal II, Courier, Dec. 20, 1852. 
No sooner had the depot grounds been located than a proposal was made by C. A. Olmstead and Company of Louisville to erect machine shops where they could construct 1000motives, rolling stock, and machinery of all kinds. The Directors, believing this proposal to be greatly advantageous to the Company, accepted Immediately and a plot of the ground was assigned whereon shops were erected almost at once, and in the Fall of 1852, Olmstead and Company announced their readiness to receive and execute orders.

All of the plans having been duly carried out, construction on the First Division was begun December 18, 1852, and the first eight miles of track were completed on August 22, 1855. 
CONSTRUCTION 
CHAPTER IV

CONSTRU CTION

Work on the First Division began on December 18, 1852. For two years construction went along nicely, but in May, 1854, work had to be suspended for several reasons. In the first place, money was scarce all over the country and the Company found it very hard to collect any cash at all. In order to continue work it became necessary to send Mr. L. L. Robinson to London to secure funds. He entered into contract with a London banking house ${ }^{l}$ for the sale of. approximately $\$ 2,500,000$ worth of first mortgage bonds, to be delivered on or before July 1, 1853. Before the sale of bonds could be ratified, however, it was necessary that a contract for the construction of the road be executed. This was done, as has already been stated, but it became impossible to deliver the bonds on the specified date. A contract was made with a Cinoinnati firm for the engraving of the bonds. These bonds had to be dated, numbered, signed, and countersigned by

1. The name of the banking house is not recorded in any of the records now in possession of the $L$ and N Railroad Company. 
the President and Secretary, and by instructions from the purchasers received on June 13, 1853, they had to be indorsed with a convertible clause and signed by the President and Secretary. The certificates of the Governors of Kentucky and Tennessee had to be obtained also. In spite of these difficulties, the bonds were dispatched to London on June 28, 1853, which was, however, too late to allow them to arrive by July 1. The war between the Russians and Turks, as well as general crop fallure, so disturbed the money markets of the world that the Lond on firm declined to take the bonds when they arrived. 1

This fact was not known here for some weeks and a great deal of criticism was showered upon the company. The trouble was cleared up, however, when President Shreve published an open letter in the Louisville Courier of January 2 , 1854.

President Shreve then set out for New York where he hoped to sell securities amounting to about $\$ 200,000$, but reported on his return that

1. Louisville Courier, January 2,1854 . 
the prices offered were ruinous, and recommended that no sales be made. 1

Added to this was the mi sunderstanding concerning iron rails. One hundred and fifty-six tons of rails had been received from Gill, Hardeman, and Stevens of Wheeling, Virginia, under the contract that called for 1,536. Because of this shortage of rails it would have been impossible to continue the work eren if the financial troubles had not arisen. 2

At this time the stockholders and friends of the $\mathrm{L}$ and $\mathrm{N}$ Railroad Company were becoming more and more suspiclous of the Company's contract with Morton, Seymour and Company. In spite of the fact that prices all over the country had fallen extremely low this company was still receiving the price contracted $f$ or at the beginning of the road. The directors soon saw that it would be necessary to cancel this contract if they expected to keep the stockholders on their side. It was not, however, as easy to roid this contract as they thought it would be. The Company thought it owed Morton

1. City Journals, 1854-55.

2. Report of Chief Engineer, 1855, pp. 19-20. 
Seymour and Company about $\$ 95,000$. The contractors insisted that the debt was more than that. After much arguing the directors ordered a remeasurement of the work already done. This remeasurement began on January 15, 1855, and proceeded until over 45 miles had been measured. It was found hard to prove that either was wrong and so to avoid a long legal struggle and to take advantage of the low prices which might be secured by new contracts it was decided to make a settlement. A compromise was reached which looked disadvantage ous for the $L$ and $N$ at that time but af terwards proved beneficlal. The Company delivered county bonds to the extent of $\$ 107,000$ to the contractors for their debt of $\$ 95,000$ or more. 1

By September, 1855, the financial clouds which had been so heavy at the beginning of the year had been dispelled to some extent. Through vigorous measures the management convinced the public that the road would be completed and the general morale was again largely restored. The President and Board assured the people in regard

1. Report of President and Directorg, 1855, pp. 5-6. 
to the operation of the thirty miles adjacent to Louisville by December, 1855. The counties in both Tennessee and Kentucky had issued their bonds and were levying taxes to take care of the interest. The contract with Morton, Seymour and Company had been cancelled and another made with Justin, Edsall and Hawley. ${ }^{1}$ The bonds which had been sent to Europe were again safely in the hands of the company, ready for sale or cancellation. The Company was at last free from embarrassment and the work was recommenced in September, 1855 with renewed vigor and enthu si asm.2

After the work was resumed the Directors turned their attention to the proposed branches of the road. In order to obtain another bond issue of $\$ 1,000,000$, needed to cinch the completion of the entire road, 3 the stockholders through the Directors pointed out the advantages of bfanches to Lebanon and Glasgow. The Lebanon Branch would command for Louisville markets the

1. Report of President and Directors, 1855, pp. 20.

2. Ibid.. p. 7 .

3. Ibid., pp. 11-12. 
products of Washington, Marion, Taylor, Green, Adair, Russell, and Casey Counties. ${ }^{1}$ The branch to Glasgow would secure the trade of a large hinterland. A branch through Grayson County was suggested as a good one because such a road would traverse the rich mineral section and coal fields of western Kentucky and terminate at Columbus, or some other point on the Mississippi. It would be possible to connect with the Great Pacific Railroad, the eastern terminus of which, it was believed, had been in effect already fixed by Congress at Cairo. ${ }^{2}$

The advantages of the Nashville connection were again enumerated in an effort to persuade the people of Louisville still further. By means of the Nashville and Chattanooga Railroad, a connection would be formed with two great trunk roads. From these trunk lines, one running to Savannah and the other to Charleston, access would be had to the entire southeast. 3 The promoters declared that "the Louisville and Nashville

1. Report of President and Directors, 1855, p. 12.

2. Ibid.. p. 14.

3. Ibid., p. 14. 
Railroad would from Bowling Green to Louisville, form a connection link between the great system of roads projected and being projected in the South, and Southwest, and the North, and Northe ast." 1

This plan was met with great enthusiasm both by the people of Louisville and those living in the counties through which the proposed branch roads would go. The City of Louisville subscribed for another $\$ 100,000$ worth of stock to help finance the branch roads. 2 The location was made in the spring of 1854, and the first fifteen miles were alloted by Morton, Seymour and Company for construction. Several months were lost when the work was suspended on the entire road, but the people of Marion County insisted that the remaining twenty-two miles be placed under contract. The Board of Directors announoed that the contract would be let on December 15, 1854, the work to be divided between several contractors. $\$ 134,000$ had been expended by September l st and

1. Report of President and Directors, 1855, pp.15-16. 2. City Records 
it was estimated that the month of September would add $\$ 30,000$ to the total. A good bit of the masonry was already erected, bridges were ready to be set up, and the forecast was made that the branch could be completed by June, 1856, if the force was maintained. ${ }^{1}$ The road mas actually completed in November, 1857, just a little over a year from the estimated date. 2

The estimates of cost for the proposed Memphis Branch were submitted during the year by the Chief Engineer. The estimates $f$ or the three possible routes, entirely equipped for operation, are summarized as follows: 3

Russellville route, $78.5 \mathrm{miles}-\quad-\$ 980,462$. Central route, 45.5 miles - - - 960,361 . Franklin route, 34.5 miles - _ - 756,542 .

From the standpoint of engineering difficulties the latter two routes were the easier. On these two routes there would be no grade over lifty leet, and the amount of straight line by the second route is forty-four miles, and by the third, thirty-two

1. Report of Chief Engineer, 1855, p. 32.

2. Report of President and Directors, 1857, p. 12.

3. Ibid., p. 13. 
miles. On the Russellville route, the grades would sometimes be as high as sixty peet to the mile, and the radius of curvature as low as one-half mile. The Chief Ingineer favored the central route as being the most economical. The Russelloille route had one strong argument in its favor; the Logan County subsoription of $\$ 300,000$, and individual subscriptions of $\$ 100,000$ from subscribers living in Logan and Todd Counties. It was determined in December, 1856, to place the work under contract, but the urgent remonstrances of some citizens of Logan County caused a postponement of the contracts. By Ootober, 1857, no contracts had been let. ${ }^{1}$

The management was insistent that the Memphis Branch be pushed to completion. Terms had already been made between the Louisville and Nashville Railroad on the one hand, and the Memphis and Ohio Railroad, and the Memphis, Clarksville and Louisville Railroad, on the other. The amount of subscriptions already secured was estimated to be suffiolent to grade the road, at which time the credit of the branch would be sufficient to equip it.2 The branch

1. Report of Chief Engineer, 1857, pp. 27-30. 2. heport of President and Directors, 1857, pp. 14-15. 
was completed and ready for traffic by september 13. 1860.1

The total cost of the Lebanon Branch was quoted as $\$ 1,007,736 \cdot 13$ and that of the Memphis Branch as $\$ 848,733.49$.

Few ohanges had been made since the organization of the Company in 1851. Mr. Shreve was still president and the original directors still held their places. In October $1856 \mathrm{Mr}$. Shreve handed in his resignation. Stories of $\mathrm{Mr}$. Robinson and $\mathrm{Mr}$. Shreve being connected with a scandal, charging them with having had an interest in a tunnel job, were going around. 2 Not only that but the stockholders did not feel that work was progressing fast enough. Finally the Aldermen of the City of Louisville called for an investigation and the resignations of both Mr. Robinson and Mr. Shreve followed. 3 The Board of Directors did not, as a body, believe in Mr. Shreve's gullt. Several meetings were held before they could be persuaded to accept his resignation and elect a new president. On October 18, 1856, however, the seven directors elected ex-governor John L. Helm as president of the Company. Benjamin Spaulding was

1. Secretaries Report of October, 1860, pp.12-13, 15-16. 2. Louisvilie Post, Augu st 16, 1922.

3. Louisville Post, August 16, 1856.-City Records, 1856-57. 
made vice-president and the seven original directors were re-elected. 1

It was not until 1859 that another important change took place. President Helm had been qui te 111 during most of his term as president and a greatdeal of the work naturally fell to the new Vice-president, James Guthrie, elected in 1857. Finally in November, 1859, the board considered President Helm incapable and too extravagant with the Company funds and asked for his resignation. James Guthrie was elected in his place and to him goes most of the credit for the completion of the road. 2

Construction was going along rapidly and the bridge work was almost completed by June, 1859 . The Directors promised that the road would be opened by October of that year. This opening depended on several factors, however. It was necessary to finish the grading below Munf ordsville and to deliver a sufficient amount of rails and cross ties. It was estimated that 9,000 tons of railroad iron was necessary to lay the entire

1. Minutes of 1857 .

2. Clark, T. D., The Beginning of the L and N, p. 44 . 
distance with track. In the meantime the station in Louisville had been completed at a total cost of $\$ 34,000$ and plans had been made to construct an office building in Louisville at a cost of $\$ 12,000 .^{1}$ This construction work was put into the competent hands of Albert Fink, whose services had been obtained through the influence of Mr. George Maoleod. ${ }^{2}$ Mr. Fink was a German by birth and had come to this country only a few years before coming to Louisville. He was only here a few years before being appointed general superintendent of the entire road. The freight and passenger station which he designed was erected on the corner of Ninth and Broadway. The shed was 400 feet long by 153 feet wide, and contained six tracks. This station still stands and is in good condition to-day, although it has been widened and converted to the use of freight only. 3

When the above mentioned buildings had been completed in Louisville the station at Bowling Green was contracted for. This contract also included an engine house, designed to accommodate the

1. Report of Chief Engineer, 1858, p. 31.

2. Wilkes, J. G., "Albert Fink, Railroad Pioneer," L and N Employes' Magazine, August, 1927, pp. 9-10.

3. Ibid., p. I1. 
business of the Memphis Branch. A station at Franklin was planned on the model of the one at Elizabethtown. Two freight sheds were under construction at Bacon Creek and Munf ordsville. ${ }^{1}$

By the middle of June, 1859, passengers were making. the trip from Nashville to Louisville in twenty seven hours. They left Nashville at 3:30 p.m. and travelled by rail to Franklin, there they took the night stage which put them in Munfordsville in time to make connections with the train which arrived in Louisville at $6 \mathrm{p.m.}$

On the northern portion of the road trips were extended on July 5 to Rowlett's; on August 3 to Horse Cave; and on August 10 to Ritter's, 84 miles from Loulsville. Trains al so began running from Nashville to Bowling Green on August 10,1859, and the travelling time between Louisville and Nashville was reduced to sixteen hours. 3

The last rail was put into place on the Kentucky side on October 8, 1859. Ten days later the Tennessee crew finished their work and on October 31,1859 , the first through train was run

\footnotetext{
1. Report of Chief Engineer, 1858, p. 31.

2. Louisville Courier, June 13, 1859.

3. Report of superintendent, $1859, \mathrm{p} .23$.
} 
IST DIVISION

2ND

3RD

$-4 T H$

TOTAL

BRANCH ROADS

- LEBANON BR. 37.50 "(Mayl854-Nov.1857)

- MEMPHIS BR. 46.50 " (May 1856 - 1860)

TOTAL MILEAGE $\underline{\underline{269.45}}$


GUTHRIE
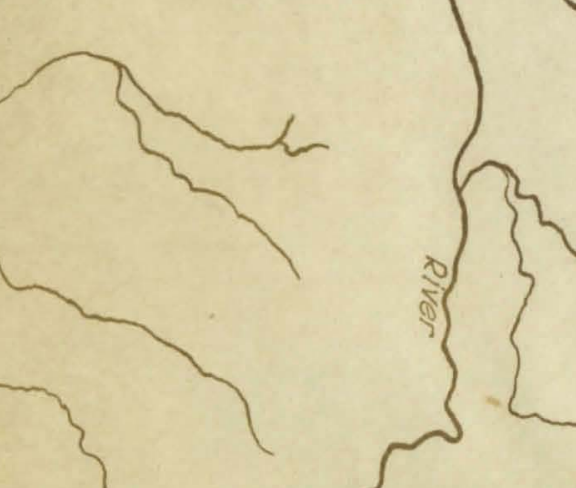

ThM TENNESSEE
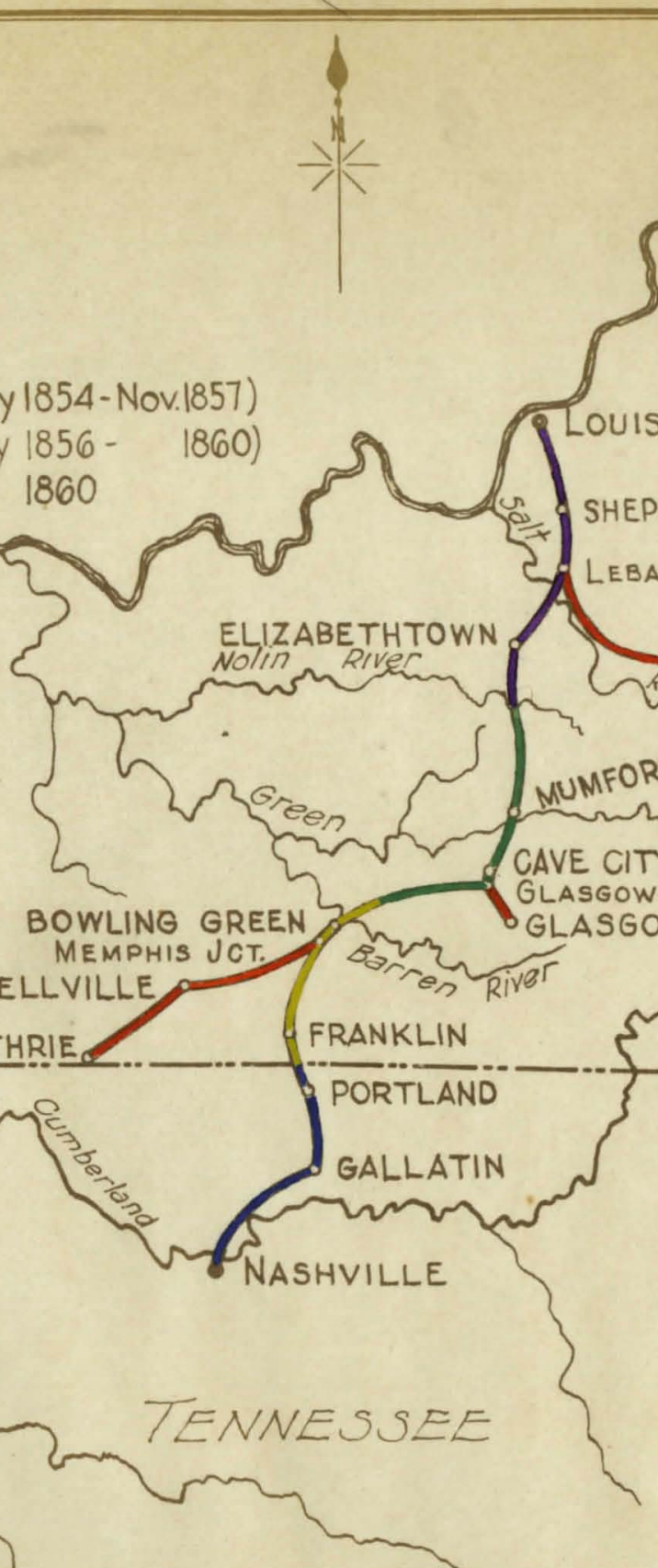
from Louisville to Nashville. In charge of the train was Captain Alfred Pirtle, a distingui shed citizen of Louisville. ${ }^{1}$ The operation of regular through trains began on the first Monday in November. The time table effective on and after Monday, October 31, 1859, showed that two passenger trains were run each way between Louisville and Nashrille.each day. One train left each city in the morning and another in the afternoon, with the total running time averaging between eight and nine hours. ${ }^{2}$ One regular freight train was scheduled in each direction, with one running from Louisville to Lebanon Junction, and from Nashville to Gallatin. It was the ruling of the company that only one passenger train was to operate on Sunday and no freight train. Local freight trains were made up as the trafic demanded. 3

1. I and N Employes' Magazine, March, 1925, p. 24. 2. Time Table, October 31, 1859 .

3. Report of President and Directors, 1859, p. 4. 
FINANCES 
CHAPTER V

\section{FINANCES}

On May 30, 1855 the Secretary, in his report to the stockholders, gave the following information concerning the financial condition of the Company at this date. The total actual expenditures of the Company were $\$ 921,840.23$. This was just a little over the figure of the previous year. The total resources of the Company, exclusive of the prospective Tennessee aid, were represented as being $\$ 1,597,308$ par value. The outstanding floating debt of the Company was about $\$ 45,000$. The Lebanon Branch had assets of $\$ 522,236$, \$297,236 of which was composed of individual and county subscriptions, the remainder being the loan of Louispille city bonds authorized by ordinance of the city council. I Excluding costs of depots and the cost of rolling stock, which was to be the same used on the main line, the total estimated cost of the road to Lebanon f rom Lebanon Junction was $\$ 599,110.2$

1. Report of Secretary, 1855, p. 17 .

2. Report of Chief Engineer, 1855, p. 32 . 
In 1855 the City Council of Louigville authorized an additional subscription to the stock of the Company to be pald by three issues of bonds as follows: April 1, 1856, $\$ 500,000$; October 1, 1856, $\$ 250,000$; April 1, 1857, $\$ 250,000$, making a total of $\$ 1,000,000.00$. The se bonds were to run $f$ or thirty years and bear six per cent interest, payable semi-annually. The principal was to be met by a sinking $f$ und and provisions were made for interest as it came due. ${ }^{1}$

A brief survey of the estimates and the available resources to meet those estimates will show at this time the financial progress of the Company during the year 1856. By the end of the year 31 miles of the main line from Louisville were in operation, together with three or four miles on the Lebanon Branch. Between Lebanon Junction and Section 76 the estimated cost of gradation was $\$ 1,103,877$. To meet this there were the bonds of Hart and Hardin Counties, including arrears of interest, to the amount of $\$ 400,000$, and bonds of the city of Loulsville under the new subscription of $\$ 1,000,000 .^{2}$

1. Report of President and Directors, 1856, p. 4. 2. Ibid., p. 5 . 
It became necessary to appoint a superintendent of the road, and so in February, 1856, James F. Gamble was selected for the job. In the possession of the Company at that time were two locomotives, one of which was damaged, trenty five cars, including one baggage car, five open cars for hauling rock, two hand-cars, and seventeen flat cars. A mixed preight and passenger train made a round trip daily to Salt River. On April 9 the run was extended to Long Lick, a distance of 22 miles from Louisville. On May 15 a further extension was made to Crooked Creek, and on June 9, to Lebanon Junction. ${ }^{1}$ On March 1, 1856, the Company purchased a second-class passenger car from the Louisville and Frankfort Railroad. By October of 1856 passenger cars constructed in the Company's own shops were in operation. Two new locomotives mere bought and two first class passenger cars whioh had been ordered were received. Thls brought the total number of locomotives to four, and the number of cars of all kinds to fifty-nine, among which were Included four passenger cars. The superintendent

1. Report of Superintendent, 1856, p. 36 . 
repor ted revenues of $\$ 16,000$ from passengers and freight between February 1, and september 5, 1856. No damages were incurred because of killing or injuring livestock, and although two persons were killed by trains, both were unavoidable accidents and no damages were pald. At the end of the fiscal year, there were seven men immediately connected with transportation, one assistant conductor, three brakesmen, one engineer, one fireman, and one recelving clerk. The aggregate wages of all of these was about $\$ 229$ per month. This with the estimated amount of wood used, water supply, 011, and waste would make the immediate expenses about $\$ 320$ monthly. ${ }^{1}$

Up to Ootober 1, 1856, the total expenditures of the Company amounted to $\$ 1,467,250.26$. This meant an expenditure during the fiscal year of about $\$ 500,000$. Most of this amount was spent for gradation cost, lands for depots and rolling stock. The total amount of assets on hand available for construction purposes was $\$ 1,533,523.54^{2}$ If other assets available in the near future may be added, the total available assets amounted to $\$ 2,522,735.12 .^{3}$

1. Report of Superintendent, 1856, pp. 37-38.

2. Report of Secretary, 1856, p. 34 .

3. Ibid., $\mathrm{pp}$.34-35. 
The revised estimates of the road were summarized by the Chief Engineer as follows:'

Lebanon Junction to Bacon Creek-- $\$ 482,225$ Bacon Creek to Warren County line- 461,519 Warren County line to Tenn.Iine--- 320,659 Tenn. line to Edgefield-_..... 565,577 $\$ \overline{1,829,980.00}$

The remaining necessary expenditures amounted to about $\$ 4,300,000.00 .^{2}$

Two locomotives, the New Haven and Marion, were added on September 20, 1857, making the total number now owned by the company six. Thirty-one oars were built in the shops during that year. During this same year damages were very trivial. One horse was killed, a brakeman's foot injured and $\$ 20$ worth of goods damaged were the only accidents oited in the Superintendent's report of 1857.3

The total expenditures of the road, by October, 1857, had risen to $\$ 2,289,150.19$, an increase of about $\$ 820,000$ over the report of the previous year. The assets on hand were listed at $\$ 1,704,502.08$. The total stook liabilities amounted to $\$ 43,607,229$. For the first time, the report of the secretary showed a profit and loss account with a balance of

1. Report of Secretary, 1856, p. 34 .

2. Report of Chief Engineer, p. $68,1856$.

3. Report of Superintendent, 1857, p. 36. 
$\$ 44,175.60$. Expenditures on the Lebanon Branch had reached a total of $\$ 797,268.04$ with the unexpended means totaling about $\$ 200,000 .^{1}$

Estimates of the revenues of the road were made in 1858. Since the Louisville and Frankf ort Railroad was in 1858 earning about $\$ 4,000$ per mile in gross revenues, the $L$ and $N$ expected to raise that figure to $\$ 5,000$, counting on the Memphis section to give a total gross revenue of $\$ 926,000$. If an operating ratio of 45 per cent is assumed, and the annual fixed charges are calculated at $\$ 177,300$, the sum of $\$ 230,400$ would remain over and above the cost of operation and payment of interest. 2

Three trains were running daily now and were always crowded. Iron, grain; hogs and tobacco were the ohief articles brought to the city by the new railroad. The receipts from the preceding six months were quoted as being greater than those of any road in the west operating under similar conditi ons. 3

By September 27, 1858, trains were running to Upton. No accidents to employees or passengers

1. Report of Secretary, 1857, pp. 30-32. 2. Report of President and Directors, 1858, p. 7 . 3. Ibid., p. 48 . 
were listed in that year. The cost of operation was said to be 41.8 per cent of each dollar of receipts, allowing for depreciation to iron and bridges. 1 Four locomotives were purchased, two from Moore and Richardson in Cincinnati, and two from Baldwin in Philadelphia. The company omed at the beginning of the year in October, 1857, a total of 84 cars. Sixty more were added, making a total of 144. The passenger car mileage made during the year was 294,467 ; the freight oar mileage, 635,511. Progress was made on all sections of the road and the table below shows the expenditures on the various sections up to september, $1858:^{2}$

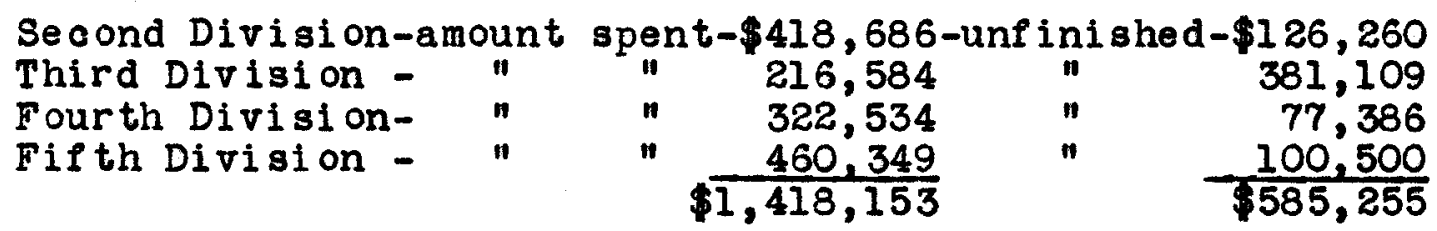

This shows an increase of $\$ 65,274$ over the estimate of the preceding year. This was explained by the fact that the bridge structures brought up several unexpected difficulties. Then too, the Green and Barren bridges were to be entirely of iron, and the bridge over sulphur Fork nearly so. 3

The financial condition of the Company at the

1. Report of Superintendent, 1858, p. 40 .

2. Report of Chief Engineer, 1858, pp. 26-27.

3. Ibid., p. 28 . 
end of the construction period was exceptionally strong as contrasted with the vicissitudes of preceding years. The total expenditures of the road to February 1, 1860, exclusive of the Lebanon Branch, were $\$ 6,127,292.15$. This represents an expenditure during the year 1859 of about $\$ 2,200,000$. $^{1}$ By October 1, 1860, the total expenditure was $\$ 6,674,248.53$. The most important financial achievement of that year, however, was the sale of mortgage bonds to the extent of about one and one-half million dollars. The credit for having accomplished this feat goes mostly to James Guthrie. 2 This raised the total mortgage bonds to $\$ 2,000,000$.

The actual financial statement made by the Secretary, Willis Ranney, dated October 1, 1860 and presented to the President and Directors upon the completion of the entire road, follows: ${ }^{3}$

1. Report of Secretary, 1859, pp. 18-21.

2. Louisvilie Courier, February is, 1859.

3. Report of seoretary, 1860, pp. 2-6 
Main Stem

Expendi tures

To lands for road and stations

Depot grounds

$\$ \quad 96.073 .90$

$101,971.55$

Locomotive works

$84,502.10$

Grading and Masonry

$2,279,331 \cdot 34$

Railway Superstructure

$1,612,027.70$

Equipment

$537,655.33$

Interest and di scount $333,830.63$

Interest on city of Louisville stock

Interest on County

stock Bonds

$337,500.00$

$448,582.53$

$1,119,903.16$

Miscellaneous

$842,484.53$

$\$ 6,674,248.53$

Re sources

Mortgage Bonds

$\$ 265,000.00$

County and Lebanon Bonds

$54,200.00$

Individual Notes

$13,788.08$

Due 1 or Mail Servioe

$6,312.50$

Due from Counties for Interest

$7,359.90$

Due from Lebanon Branch

$105,312.54$

Due from Memphis Branch

$53,024.90$

Due from Machinery sold, and from Sundry persons.

$39,006.85$

Shop stock and stores on hand

$37,117.12$

Fuel on Hand

$31,817,12$

$\$ 7,287,188.05$ 
Credits

By capital stock (stock issued)

$\$ 2,131,330.00$

By Interest Subscribed stock

(not is sued)

$157,657.35$

By County Subscriptions paid

(not is sued)

$1,300,000.00$

By Indiridual Subscriptions paid (not is sued)

$73,935.74$

By City of Louisville taxes

(not is sued)

$127,271.06$

By Interest stock Liability on

city bonds (stock not issued)

$136,074.98$

By Interest stock Liability on county bonds

\section{$403,882.53$}

$\$ 4,330,151.66$

Liabilities

Bills payable

$\$ 360,574.86$

Due to Contractors

$13,411.43$

Due to sundry persons

$12,967.82$

$386,954.11$

Transportation Department

$12,196.75$

Transportation Prior

Mortgage Bond Account

$2,385.53$

$14,582.28$

State of Tennessee

$\frac{2,385.53}{\$ 2,000,000.00} 14,582.28$
$550,500.00$
$\$ 2,555,500.00$
$\$ 7,287,188.05$


Lebanon Branch

Expendi tures

Grading and Masonry

Railway Superstructure

Interest and Discount and

Interest on County stock bonds

Mi soellane ous

Real Estate Bills receivable

By capital stock

Credits

By Mari on County

Individual Subscriptions paid

Individual Marion County

Interest Stook Liability

Due Main Stem

Due Sundry Contractors

City of Louisville Bonds Loaned

Income Bonds $\begin{array}{r}318,387.41 \\ 324,258.91 \\ 218,882.79 \\ 145,883.02 \\ \hline\end{array}$

$\$ 1,007,736.13$

$\frac{619.29}{\$ 1,008,355.42}$

$\$ 186,200.00$

$200,000.00$

$49,956.38$

$65,780.00$

$501,936.38$

$\$ 105,312.54$

$\frac{1,106.50}{225,000.00} \$ 106,419.04$

$175,000.00$

\section{$\frac{400,000,00}{1,008,355,42}$}

Memphis Branoh

Expendi tures

Railway Superstructure

Grading and Masonry

Interest and Discount

Miscellane ous
$\$ 354,351.02$

$307,592.81$

$89,436.19$

$97,353.47$ 
Resources

Logan County Bonds

City of Louisville

Mortgage Bonds

Due from Sundry Persons

Credits

By Capital stock

By Individual Subscriptions

By Logan County

By City of Louisville

By Interest Stock Liability on $\mathrm{C}$. Bond $\mathrm{s}$

Liabilities

Bills payable

Due to Contractor

Due to Main Stem

Due to Sundry persons

Mortgage Bonds Account

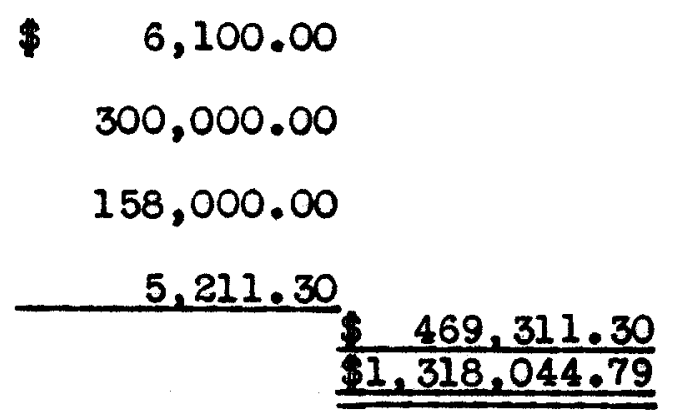

$\$ 21,190.00$

- $58,203.25$

$300,000.00$

$300,000.00$

$27,000.00$

$\$ 706,393.25$

$\$ 216,445.59$

$37,097.20$

$53,024.90$

$5,083.85$ 


\section{Consolidated Statement \\ Total Cost to date}

Main Stem

Lebanon

Me mphis

Main Stem

Lebanon

Memphis

Main Stem

Le banon

Memphis

Main Stem

Lebanon

Memphis

Main Stem

Le banon

Memphís

$\$ 6,674,248.53$

$1,007,036.13$

$848,733.49$

$\$ 8,530,718.15$

Re souroes

$\$ 454,602.08$

619.29

$469,311.30$

Total

Liabilities

Capital Stock

$\$ 4,330,151.66$

$501,936.38$

$706,393.25$

$\$ 5,538,481.29$

Floating Debt

$\$ 401,536.39$

$1,106.50$

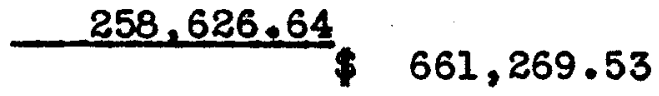

Bonded Debt

$$
\begin{aligned}
& \$ 2,555,500.00 \\
& 400,000.00 \\
& 300,000.00
\end{aligned}
$$


The operating aspects of the road looked very bright at this time. One hundred and six cars were added to the rolling stock in 1859 , making a total of 246 cars for the entire system. The passenger car mileage was 313,756 ; freight dar mileage, 674,686; with a total locomotive mileage of 233,969 . The running expenses for the year ending October 1,1859 , were $\$ 160,388.54 .^{1}$ In the same period of time the passenger traffic showed a sharp upward tendency. The number of passengers carried on the main line was 85,958 , and on the Lebanon Branch, 35,838. Almost all classes of freight showed great increases. Some of the more noticeable were: ${ }^{2}$

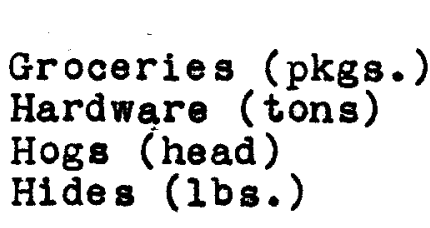

$$
\begin{array}{r}
1858 \\
37,462 \\
113 \\
24,938 \\
116,400
\end{array}
$$$$
\begin{array}{r}
1859 \\
69,734 \\
13,443 \\
60,298 \\
221,707
\end{array}
$$

The total net earnings of the main line for the period 1856-59 were: ${ }^{3}$

$$
\begin{aligned}
& 1856 \text { - _ _ - } 6,676.73 \\
& 1857 \text { - - - - } 37,498.87 \\
& 1858 \text { - - - - 74,962.93 } \\
& 1859 \text { - . - . - 141,860.86 }
\end{aligned}
$$

1. Report of the Secretary, 1859, p. 29 .

2. Ibld.. p. 33 .

3. Report of President and Directors, 1859, p. 8 
During 1858 the line was only operated an average of forty miles for the entire year, and in 1859,110 miles. The estimated gross receipts for 1860 were $\$ 693,000$. $^{1}$

The road was not overcapitalized, as many of the great roads of this day were. The capital stock of the entire system was $\$ 5,862,534$ to which we can add a debt of $\$ 4,705,500$ (and these figures include both main line and branches), making a total of $\$ 10,568,034$. For the 270 miles this would be an average of $\$ 39,139$ per mile. To pay the fixed charges, as well as six per cent upon the capital stock would require gross earnings of $\$ 5,000$ per mile. This estimate was based on the assumption that the operating ratio would not exceed fifty per cent. 2

The $\mathrm{L}$ and $\mathrm{N}$ may be called a pioneer in the development of this fertile southern territory. By reason of its constructive policies, economical operation, and the fact that it operates through a section remarkably rich in resources, it is regarded as one of the most substantial and reliable railroads in the country. During all of its four-score years it has constantly striven to provide the best possible

1. Report of President and Directors, 1859, p. 8 2. Ibid.. $\mathrm{pp} \cdot 8-9$ 
service to its patrons; it has weathered the financial storms; it has not changed 1 ts corporate name; it is one of the few large railroads in the country that has never been in receivership. Throughout all these years it has never failed to meet its obligations to the public, to pay every dollar to its workers, its creditors, and its bondholders; and, with only fourteen exceptions, it has paid dividends to its stookholders each year since 1864. Its dependability has so long been a tradition of the south that it is affectionately known everywhere as "The Old Reliable."l

More than $95 \%$ of the $L$ and $N$ mileage is located below the Ohio River, and its lines and those of affiliated companies extend into ten states of the South, serving a population of over 27,000,000 people, where its investments aggregate over one-half billion dollars, and where it operates or controls approximately 8,000 miles of railroad devoted to public service. For more than 70 years, or since the first portion of its main line was completed in 1859 , it has been actively serving the people of the South. It has gone along with them in matters of mutual interest and development, and through the payment of its Executive Secretary, Louisville office. 
proportion of taxes in the various cities, counties, and states, now amounting to $\$ 5,500,000$ annually, and by the employment in its operation of great numbers of forces who live and transact their business in the South, it naturally feels it has been instrumental in no small way in helping to give that vast territory the prominent position it holds to-day. ${ }^{1}$

It is interesting to note in conclusion that when this gigantic project was undertaken Louisville was strictly a river town of some 40,000 population whose business was principally measured by 1 ts boat trafic. Nashville was a. city of only 10,000 people. Between the two cities lay a sparsely settled country with rugged hills that offered almost insuperable barriers to the work. The project was therefore a speculative enterprise indeed. Nevertheless, after six years of effort in the face of undreamed of difficulties, -a general scarcity of money aggravated by the Crimean War, impatient and clamoring contractors, shortage of provisions among the laborers because of an unprecedented drouth, the epidemic of cholera

1. From disoussions with $\mathrm{Mr}$. Elder. 
which scattered the forces and impaired the work,-in spite of all these obstacles this huge task was finally completed, but not until it had become necessary for the directors to take the work from the contractors and complete it by using company forces and by letting portions to the farmers along the way who permitted their slaves to assist in its construction.

The most significant facts brought out by this study are:

1. The movement for the $L$ and $N$ was part of a widespread American interest in railroad construction during the period 1845-1860.

2. The city of Louisville was chiefly responsible for the establishment of the $L$ and $N$. Louisville business men feared loss of trade if Nashville obtained superior transportation facilities to western Kentucky and Tennessee. Louisville newspapers aroused public interest and brought about. passage of the railroad charter by the state legislature.

3. The municipal government of Louisville subscribed and the taxpayers paid for half $\left(\frac{1}{2}, 000,000\right)$ of the total capital stock of the main line plus $\$ 525,000$ for the branch roads and $\$ 4,000$ for the first survey. Most

1. From discusgions with Br. J. J. Elder. 
Most of the remaining stock was subscribed by counties along the railroad (five in Kentucky and one in Tennessee).

4. Individual stock subscriptions amounted to a very small portion of the total. Some individuals paid their subscriptions by allowing the use of their slaves for construction work.

5. Efforts to borrow additional funds in Europe and New York were at first unsuccessful, but later $\$ 2,000,000$ was borrowed on a mortgage bond and $\$ 550,500$ from the state of Tennesser.

6. Because of financial and engineering difficulties the work of construction progressed very slowly for the first four years (1853-7). After James Guthrie became vice-president (1857-59) and president (1859) the road was rapldiy pushed to completion (1859) including the two branch lines to Lebanon and Memphis.

7. The total cost of the original railroad (main ine plus the Lebanon and Memphis branches) was $\$ 8,531,718.15$. The cost of the main line $(\$ 6,674,248.53)$ was only about 79\% of the estimate made by the Chief Engineer in 1854. Th1s could partly be accounted for by the general fall of prices during the period of most active construction(1355-60). The cost of the branch lines, however, was considerably above the estimates. 
BIBLIOGRAPHY 


\section{BIBLIOGRAPHY}

\section{Sources}

Annual Reports, Loui sville and Nashville Railroad Company, 1851-60. These reports were voluminous, accurately written, and complete. They represent the best source of information on the subject. There is only one known copy of these reports in existence.

Charter of the Loui sville and Nashville Rail road with Amendments, publi shed by the Company. The original charter is also in the vault of the Louisville and Nashville Railroad Company Louisville office.

City Journals of Louisville, 1850-1860.

Corporate History of the Louisville and Nashville Ra1 Iroad Company as of June 30,1917 , published in mimeographed form by the Company. The corporation history of each unit of the present $L$ and $N$ system is included in this work also.

Historical Development of the Louisville and Nashrilie Railroad System. The contents of this book were compiled by Joseph

G. Kerr, published by the Company. 1927

Minute Books of the Louisville and Nashvilie Railroad Company, 1851 through 1860 .

Settlement with the Louisville and Neshville Railroad Company, a pamphlet publi shed by the state of Tennessee.

The Railmay Library, Slason Thompson, editor; Bureau of Railway News and Statistics, Chicago; Yearbook of 1910. 
Interviews with $\mathrm{Mr}$. J. J. Elder, Executive Assi stant of the Louisville and Nashville Railroad Company.

American Railroad Journal, 1850-66. Magazine of much importance during this period, published weekly.

Loulsville Courler, 1848-60, a democratic paper edited by W.N. Haldeman.

Harper's Weekly, February 25, 1860, contained an article on the Green River Bridge and several woodcuts.

Louispille Democrat, $1851-1860$.

Louisville Journal, 1850-1860. The most powerful of the Loui sville newspapers, controlled by George Prentice, a pioneer newspaper man of America. Favored the management of the $L$ and $N$ throughout all of its early life.

L and N Employee's Magazine, 1925-1932. Contains several articles on the early history of the company and many excellent photographs of the eariy road and equipment.

R. S. Cotterill, "Beginnings of Railroads in the Southwest," Mississippi Valley Historioal Review, Vol. VIII, no. 4 . 
R. S. Cotterill, "Southern Railroads, 1850-60," Mississippi Valley Historical Revien. Vol. III, No. 3 .

E. M. Coulter, "Effects of Secession upon the Commerce of the Mississippi Valley," Mississippi Valley Historical Revien. Vol. III, No. 3.

Charles K. Needham, "The Life and Achievements of Albert Fink," Paper read before the Filson Club, Louisville, Kentucky, in October, 1920.

\section{Secondary Works}

$A$ Book About the $L$ and $N$, published by the Company, Loui svilie, ig23.

Adams, Charles $\mathrm{F}$. Jr., Railroads. Their Origin and Problems, G. P. Putman's Sons, New York, 1880 .

Clark, T. D., The Beginning of the $L$ and $N$ Railroad, Standard Printing Company, Louisvilie, Kentucky, 1933.

Collins, Lewis, History of Kentucky, Revised by Richard H. COIIIns, John P. Morton and Company, Louisville, 1920.

E. M. Coulter and William Elsey Connelley, History of Kentucky, edited by Judge Charles Kerr, 5 volumes, American Historical Society, Chicago, 1922. 
Fiftieth Anniversary of James Geddes, 1851-1901, a memorial pamphlet publi shed by the

$L$ and $N$ Company in recognition of fifty years of service with the Company, 1901. Contains a series of addresses delivered at a banquet in honor of Jame $\mathbf{s}$ Geddes.

Hadley, Arthur Twining, Railroad Transportation Its Hi story and Its Laws, G. P. Putman's Sons, New York, 1886 .

Johnston, J. Stoddard, Memorial History of Louisville from its First Settiement to the year 1896. Two volumes. American Biographical Publishing Company, Chicago, 1896.

Kerr, John Leeds, The Story of a Southern Carrier, Young and Ottley, Inc., New York, 1933.

Laut, Agnes C., Romance of the Rails, Robt. M. McBride and Co., New York, 1929.

Thompson, Slason, A Short History of American Railways, D. Appleton and Company, New York, 1925. 